\title{
On the Interaction between Sea Breeze and Summer Mistral at the Exit of the Rhône Valley
}

\author{
Sophie Bastin, ${ }^{*}$ Philippe Drobinski, $*$ Vincent Guénard, ${ }^{+}$Jean-Luc Caccia, ${ }^{+}$ \\ Bernard Campistron, ${ }^{\#}$ Alain M. Dabas,${ }^{@}$ Patricia Delville, ${ }^{\&}$ Oliver Reitebuch, ${ }^{* *}$ And \\ CHRISTIAN WERNER** \\ *Institut Pierre Simon Laplace/Service d'Aéronomie, Paris, France \\ + Laboratoire de Sondages Electromagnétiques de l'Environnement Terrestre, La Garde, France \\ \# Laboratoire d'Aérologie, Toulouse, France \\ @ Centre National de Recherches Météorologiques, Météo-France, Toulouse, France \\ \& Division Technique/Institut National des Sciences de l'Univers, Meudon, France \\ ** Deutsches Zentrum für Luft- und Raumfahrt, Wessling, Germany
}

(Manuscript received 19 November 2004, in final form 28 July 2005)

\begin{abstract}
The three-dimensional structure and dynamics of the combination of the sea breeze and the mistral at the Rhône Valley exit, in southeastern France, have been investigated experimentally and numerically on 22 June 2001. The mistral refers to a severe northerly wind that develops along the Rhône Valley. The exit of this valley is located near the Mediterranean Sea where sea-breeze circulation often develops. The sea breeze and the mistral coexist this day because of the weakness of this mistral event.

The event was documented in the framework of the Expérience sur Site pour Contraindre les Modèles de Pollution Atmosphérique et de Transport d'Emissions (ESCOMPTE) field experiment. Several important data sources are used (airborne Doppler lidar, UHF wind profilers, radiosoundings, and surface stations) as well as nonhydrostatic mesoscale simulations.

This paper examines the various mechanisms that drive the time and spatial variability of the mistral and the sea breeze in various regions of the Rhône Valley. In the morning, the sea breeze penetrates inland near the western side of the Rhône Valley then moves back because of the reinforcement of the mistral flow caused by the deepening of the leeward surface low due to convection at noon. At midday, the sea breeze penetrates inland in the middle of the Rhône Valley only. In contrast to pure sea-breeze episodes when the sea breeze can extend inland over a horizontal range of more than $150 \mathrm{~km}$, the presence of the mistral prevents the sea breeze from penetrating more than $40 \mathrm{~km}$ onshore. In the late afternoon, the sea breeze reaches the eastern side of the Rhône Valley but over a smaller horizontal range because of higher local topography and because the mistral is more intense in this part of the Rhône Valley.

The situations of sea-breeze-mistral interactions can have a severe impact on regional air quality. Indeed, the southerly sea breeze, which advects toward the countryside the pollutants emitted from the large coastal city of Marseille, France, and its industrialized suburbs, cannot penetrate far inland because of the mistral blowing in the opposite direction. This leads to the stagnation of the pollutants near the area of emission that is also the most densely inhabited area of the region (over one million inhabitants).
\end{abstract}

\section{Introduction}

The Expérience sur Site pour Contraindre les Modèles de Pollution Atmosphérique et de Transport d'Emissions (ESCOMPTE) program (Cros et al. 2004), conducted in June and July 2001, aims at improving the

Corresponding author address: Dr. Sophie Bastin, Earth Observing Laboratory, NCAR, P.O. Box 3000, Boulder, CO 803073000.

E-mail: bastind@ucar.edu understanding and the forecast of pollutant behavior during photochemical episodes in Provence, southeastern France (region shown in Fig. 1). Indeed, this region presents a high occurrence of photochemical pollution events. On the shore of Provence, the large city of Marseille and its industrialized suburbs (oil plants in the Fos-Berre area) are sources of pollutant emission that cause frequent and hazardous pollution episodes, especially in summer when intense solar heating enhances the photochemical activity. From the dynamical characteristics of the area, the atmospheric circulation 

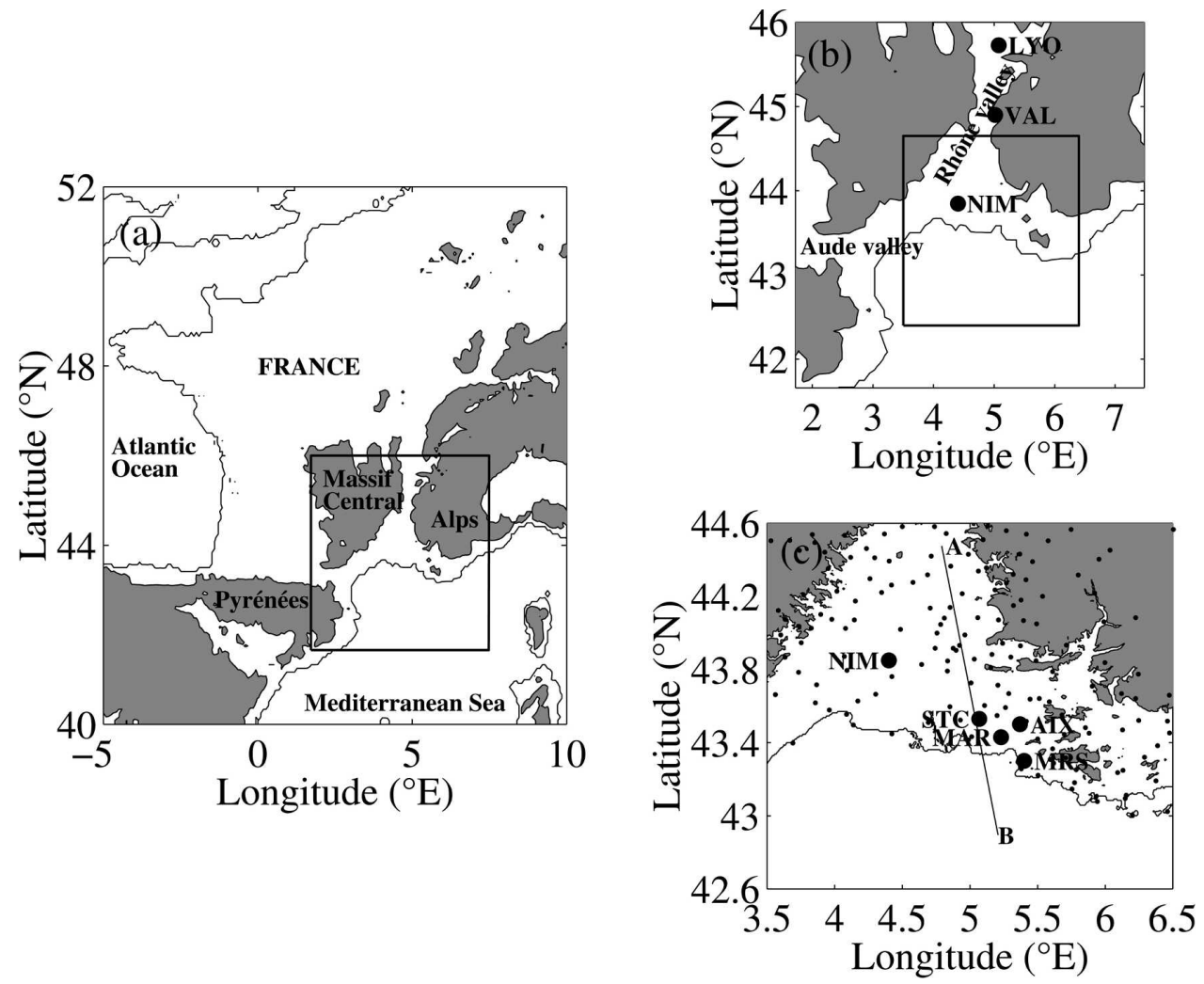

FIG. 1. (a) Map of France with the topography shaded in gray when higher than $500 \mathrm{~m}$ above sea level. The rectangle displays the large domain (hereafter called domain 1) of the Méso-NH simulations. (b) Domain 1 of the simulation with its nested smaller domain (hereafter called domain 2) in the rectangle. The acronyms NIM, LYO, and VAL stand for the city names Nîmes, Lyon, and Valence, respectively. (c) Domain 2 of the Méso-NH simulation. The solid line corresponds to a segment of the flight track of the DLR Falcon 20 carrying the Doppler lidar WIND on 22 Jun 2001, along which a cross section of the wind field is shown in Fig. 7 (A and B indicate the limits of the segment). The flight altitude is $6.5 \mathrm{~km}$ and the aircraft speed is about $170 \mathrm{~m} \mathrm{~s}^{-1}$. The dots indicate the locations of the operational meteorological surface stations operated by Météo-France. The acronyms AIX, MAR, MRS, NIM, and STC correspond to the city names Aix-en-Provence, Marignane, Marseille, Nîmes, and Saint Chamas, respectively.

over this site is highly influenced by orography. On the large scale, the French Alps (highest elevation, $4807 \mathrm{~m}$ ) and Massif Central (highest elevation, $1885 \mathrm{~m}$ ) at times reinforce a strong northerly flow, called mistral, in the Rhône Valley (e.g., Guénard et al. 2005a; Drobinski et al. 2005). On a smaller scale, the ranges of smaller mountains parallel to the coastline (i.e., Sainte Baume, Sainte Victoire, Luberon, Ventoux) tend to channel the air masses in a west-east manner (Bastin et al. 2005b). Finally, the sea-land contrasts induce the sea breeze during daytime, with advection of marine air masses as far as $100 \mathrm{~km}$ inland (e.g., Bastin et al. 2005b; Bastin and Drobinski 2005a).

During pollution episodes, the sea breeze can export inland the pollutants emitted from the Marseille urban area and the Fos-Berre plants, and the countryside is often more polluted than the area immediately sur- rounding the pollutant sources. Table 1 illustrates this point. Indeed, it shows that the ozone concentration is low at Marseille under pure sea-breeze conditions (25 and 26 June, 3 and 4 July), while pollution episodes have been predicted and occurred these days. The reason is that the ozone plume is advected farther inland (Menut et al. 2005).

In Provence, the sea breeze shares its occurrence with the mistral. The mistral refers to a severe northerly wind that develops along the Rhône Valley. The mistral genesis is preconditioned by cyclogenesis over the Gulf of Genoa and the passage of a trough through France. When the synoptic northerly/northwesterly flow impinges on the Alpine range, it splits and is deflected west by the Coriolis force as well as the pressure buildup on the northern edge of the range. As the flow experiences channeling in the Rhône Valley separating 
TABLE 1. Ozone concentration measured at Marseille and averaged between 1000 and 1600 UTC, as a function of the type of atmospheric circulation.

\begin{tabular}{clc}
\hline \hline Date & Type of atmospheric flow & $\begin{array}{c}\text { Ozone } \\
\text { concentration } \\
\left(\mu \mathrm{g} \mathrm{m}^{-3}\right)\end{array}$ \\
\hline 17 Jun 2001 & Mistral & 76 \\
18 Jun 2001 & Mistral & 81 \\
19 Jun 2001 & Mistral & 84 \\
21 Jun 2001 & Mistral + sea breeze & 140 \\
22 Jun 2001 & Mistral + sea breeze & 115 \\
23 Jun 2001 & Mistral + sea breeze & 120 \\
24 Jun 2001 & Mistral (end $)+$ sea breeze & 100 \\
25 Jun 2001 & Sea breeze & 62 \\
26 Jun 2001 & Sea breeze & 92 \\
28 Jun 2001 & Mistral & 88 \\
1 Jul 2001 & Mistral & 101 \\
3 Jul 2001 & Sea breeze & 100 \\
4 Jul 2001 & Sea breeze & 91 \\
\hline
\end{tabular}

the French Alps, to the east, from the Massif Central, to the west, by a gap of $200 \mathrm{~km}$ long and $60 \mathrm{~km}$ wide, it is substantially accelerated, giving rise to the mistral. The mistral is often strong enough to inhibit the sea-breeze flow (Arritt 1993) and to prevent any sea-breeze development along the coastline. It is even frequently observed to extend as far as a few hundreds of kilometers from the coast (Jansá 1987). It is thus associated with low pollution levels in Provence as it advects the pollutants away from their sources of emission over the Mediterranean. Table 1 shows that during the ESCOMPTE experiment, the mistral events correspond to low ozone concentration over Marseille, with one exception of the 1 July 2001 mistral case when the ozone concentration was higher than usual because high-level tropospheric ozone was incorporated within the mistral flow (Corsmeier et al. 2005).

During the ESCOMPTE field experiment, between 21 and 23 June 2001, a mistral event occurred, but its weak intensity allowed the sea breeze to break through during daytime. We believe that because of the adverse mistral flow, the sea breeze could not penetrate far inland, making the pollutants stagnate close to the coastline. This hypothesis is investigated in this study but high ozone concentration levels measured at Marseille (Table 1) tend to confirm this assumption. The paper focuses on 22 June 2001 since it is the most stationary day of the 3-day period. Specifically, this paper analyzes the dynamic processes causing the unsteady and inhomogeneous development of the mistral and the sea breeze at the small scale in the Rhône Valley.

The objectives of the paper are addressed using both the dataset collected during the ESCOMPTE experi- ment and the nonhydrostatic mesoscale model MésoNH (Lafore et al., 1998). We make use of the data from the operational meteorological surface station network, the radiosoundings, the UHF wind profilers, and an airborne Doppler lidar. In the framework of ESCOMPTE, the UHF wind profilers were used to investigate the dynamical processes that drive the time variability of the mistral (Caccia et al. 2004; Guénard et al. 2005a), or that explain the complex layered structure of ozone concentration near the coast during seabreeze events (Delbarre et al. 2005; Puygrenier et al. 2005). The airborne Doppler lidar proved to be a proper instrument to investigate the nature of the mistral (Drobinski et al. 2005) or the structure of the sea breeze (Bastin et al. 2005b) because of its ability to map the wind field in three dimensions.

After the introduction in section 1, the instrument setup and the numerical model used in this study are described in section 2. In section 3, the mistral-seabreeze event is described. Section 4 is dedicated to the evaluation of the model performance in reproducing this event. Section 5 examines the mechanisms driving the unsteady and inhomogeneous aspects of the flow structure at the Rhône Valley exit. Section 6 concludes the study.

\section{Measurements and model}

\section{a. Observations}

During the ESCOMPTE experiment, a wide range of instruments was deployed around Marseille, leading to a dense network of observations available from Doppler and ozone lidars, wind profilers, sodars, radiosoundings, and meteorological surface stations (see the details in Cros et al. 2004). The aim of this experiment was to study the role of land-sea-breeze circulations on air pollution transport at local to regional scale. The 22 June 2001 mistral case is the second day of intensive observing period (IOP) $2 \mathrm{a}$. In the present study, we mainly use the measurements from the airborne Doppler lidar, the wind profilers, the operational radiosoundings, and the synoptic meteorological stations of Météo-France. The complementarity of the data provided by these various instruments is an essential aspect of this study. The locations of the operational meteorological surface stations are shown with dots in Fig. 1c.

\section{1) RAdiosondes AND IN SITU SURFACE STATIONS}

On 22 June 2001, operational radiosondes were released every $12 \mathrm{~h}$ from Lyon and Nîmes (see Fig. 1b). At the surface, the operational meteorological surface station network gave access to the surface thermody- 
namical field (wind, temperature, humidity, pressure). In addition to this network, few stations providing radiative flux measurements were deployed for the campaign.

\section{2) THE UHF WIND PROFILERS}

Four UHF wind profilers, manufactured by Degréane, were deployed during ESCOMPTE: they were located at Saint Chamas (STC), Aix-les-Milles near Aix-en-Provence (AIX), Marseille (MRS), and Marignane (MAR) (see Fig. 1c). The measurements consist of the time evolution of the vertical profiles of the three wind components thanks to one vertical beam and two or four oblique beams (depending upon the radar), slanted at an off-zenith angle of $17^{\circ}$, the half-power beamwidth being $8.5^{\circ}$. They work with a frequency of $1238 \mathrm{MHz}$ ( $\simeq 30 \mathrm{~cm}$ wavelength), and with a peak power of $4 \mathrm{~kW}$. Returned echoes are due to the air refractive index fluctuations advected by the wind. The wind velocity is estimated from the frequency corresponding to the mean Doppler shift obtained in the radar echo. The data quality control and processing are carried out through a consensus algorithm based on time and height continuity of measured spectra. The consensus works over a 60 -min period providing a wind profile each 15-min from a height of 100-300 m up to 2500-4000 m AGL. The vertical resolution is typically $75-150 \mathrm{~m}$. The errors on the horizontal (vertical) wind measurements are typically $1-2 \mathrm{~m} \mathrm{~s}^{-1}\left(0.25-0.5 \mathrm{~m} \mathrm{~s}^{-1}\right)$.

\section{3) THE AIRBorne DOPPLER LIDAR WIND}

The French-German airborne Doppler lidar, the Wind Infrared Doppler Lidar (WIND; Werner et al. 2001), was operated on the 22 June 2001 mistral case between 1434 and 1653 UTC. The lidar is operated at $10.6 \mu \mathrm{m}$ in the infrared spectral region and was on board the Falcon 20 of the Deutsches Zentrum für Luft- und Raumfarht (DLR; Werner et al. 2001). Between 1635 and 1653 UTC, it flew along track B-A, shown in Fig. 1c, at an altitude of $6.5 \mathrm{~km}$ with an aircraft ground speed of around $170 \mathrm{~m} \mathrm{~s}^{-1}$. At $10.6-\mu \mathrm{m}$ wavelength, the lidar signals are sensitive to micronic aerosols, which are excellent tracers of the dynamics in troposphere, therefore making WIND a relevant tool for the study of planetary boundary layer (PBL) dynamics in complex terrain (e.g., Reitebuch et al. 2003; Bastin et al. 2005b; Drobinski et al. 2005). The Doppler lidar WIND provides wind radial velocity measurements along the line of sight (LOS) of the transmitted laser beam. The wind profile is obtained by conically scanning the LOS around the vertical axis with a fixed angle of $30^{\circ}$ from nadir. The profile of the three-dimensional wind vector was calculated from the profiles of the LOS wind speeds using a velocity-azimuthal display (VAD) technique (Caya and Zawadzki 1992). A full scan revolution of the line of sight takes $20 \mathrm{~s}$, leading to a horizontal resolution of about $3.4 \mathrm{~km}$ between vertical profiles of the wind vector. The vertical resolution of the wind profiles is $250 \mathrm{~m}$, and the accuracy of the horizontal wind velocity is around $1 \mathrm{~m} \mathrm{~s}^{-1}$ (Reitebuch et al. 2001).

\section{b. Model}

The numerical simulation was conducted with the Méso-NH model that solves the nonhydrostatic and anelastic equation system (Lafore et al. 1998). Two interactively nested model domains are used, the horizontal mesh size being 9 and $3 \mathrm{~km}$, respectively. Domains 1 (coarse domain) and 2 (fine domain) are centered at $43.7^{\circ} \mathrm{N}, 4.6^{\circ} \mathrm{E}$ and cover an area of $450 \mathrm{~km} \times$ $450 \mathrm{~km}$ and $228 \mathrm{~km} \times 246 \mathrm{~km}$, respectively (see Fig. 1). Domain 1 covers the Rhône Valley, the western Alps, and the Massif Central. Domain 2 covers the Rhône Valley delta. The vertical grid is made of 50 levels with a mesh stretched between 60 and $600 \mathrm{~m}$. To insure a good description of the PBL, 12 levels are taken below $1000 \mathrm{~m}$. The size of the first nine meshes is less than $100 \mathrm{~m}$. Above $8000 \mathrm{~m}$, the mesh size is constant and set to $600 \mathrm{~m}$. The top of the domain is located at $18000 \mathrm{~m}$. A complete set of physics parameterization is used. The turbulence scheme is unidimensional on the vertical and is based upon the physical mixing length of Bougeault and Lacarrère (1989). The convection scheme is described in Bechtold et al. (2001) and is used in model domain 1 . In model domain 2 , this parameterization is not needed since convection is resolved explicitly at such high resolution. The radiation schemes, as well as the parameterization of land surface processes are described in Morcrette (1991) and Noilhan and Planton (1989), respectively. The initial and coupling fields were generated by first interpolating the European Centre for Medium-Range Weather Forecasts (ECMWF) analyses available every $6 \mathrm{~h}$ on a $0.5^{\circ} \times 0.5^{\circ}$ latitude-longitude grid to the model grid The initialization date is 21 June 2001 at 0600 UTC and the simulation ends on 23 June 2001 at 0000 UTC.

\section{The ESCOMPTE IOP2a mistral/sea-breeze event}

\section{a. Synoptic environment}

The 22 June 2001 mistral event is featured by a northwesterly flow over France resulting from an anticyclone over western France and a low pressure system over northern Europe (Fig. 2). On 21 June 2001 at 1200 UTC (Fig. 2a), a high-surface-pressure zone (1022 hPa) is 

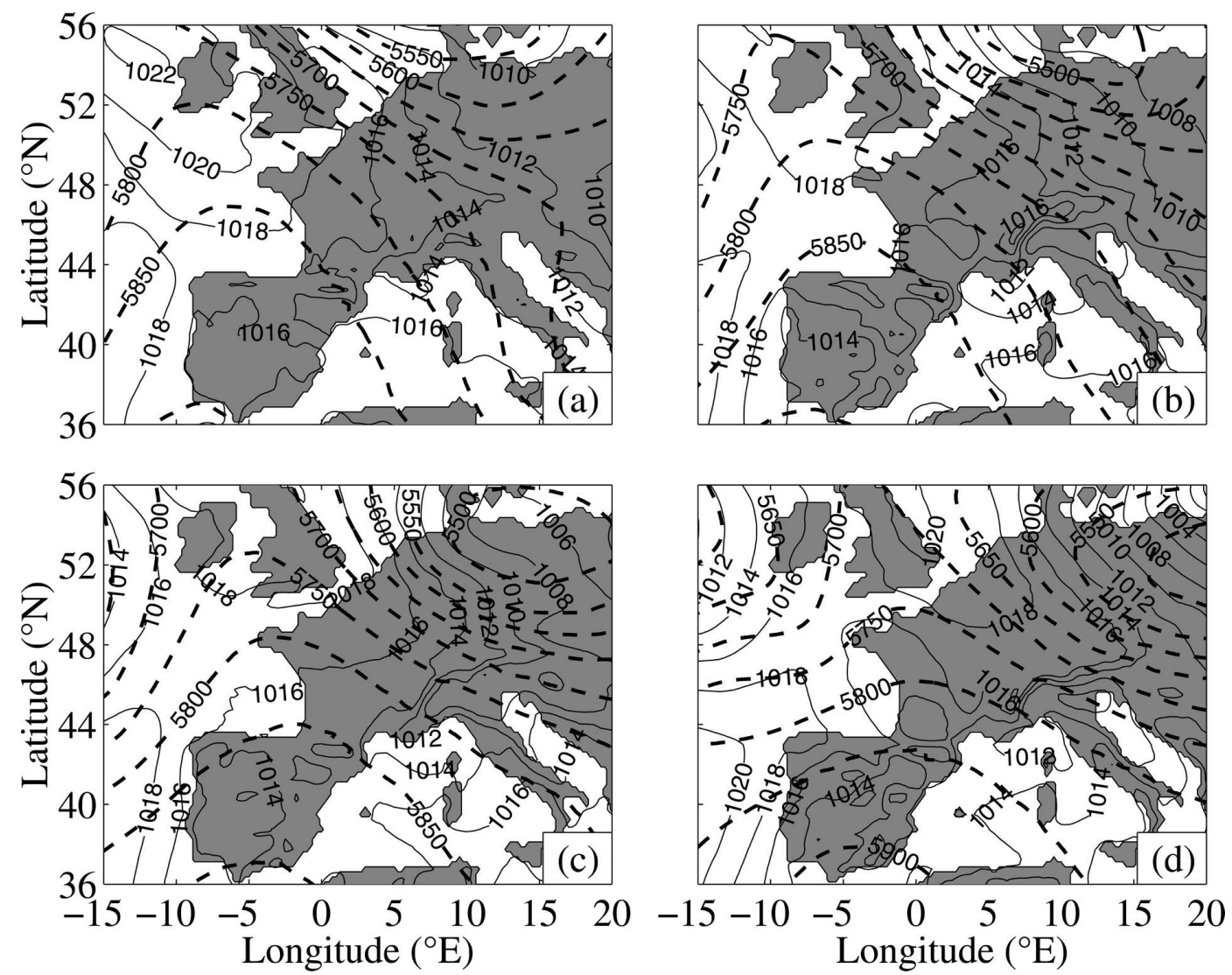

FIG. 2. Synoptic situation in 12-h intervals on (a) 1200 UTC 21 Jun 2001, (b) 0000 UTC 22 Jun 2001, (c) 1200 UTC 22 Jun 2001, and (d) 0000 UTC 23 Jun 2001 from ECMWF analyses. The mean sea level pressure and 500-hPa geopotential heights are shown with solid (the contour interval is $2 \mathrm{hPa}$ ) and thick dashed (the contour is $50 \mathrm{~m}$ ) lines, respectively.

centered over western Ireland and extends over northwestern France. In southeastern France, no significant pressure gradient prevails. This situation leads to a northwesterly surface flow and no well established flow over the western Mediterranean. Nevertheless, a weak surface low is generated $(1010-1012 \mathrm{hPa})$ in the wake of the Alps ridge, similar to a föhn knee (see example in Drobinski et al. 2003), which marks the existence of a weak mistral wind channeled in the Rhône Valley. On 22 June 2001 at 0000 UTC (Fig. 2b), the high-surfacepressure zone that was located over western Ireland moves northward, contributing to the weakening of the surface winds upstream the Massif Central and the Alps. In southeastern France, the Genoa cyclone strengthens (however, remaining weak with respect to other mistral events; see, e.g., Guénard et al. 2005a; Drobinski et al. 2005) extending from the Pyrénées to the Pô Valley. On 22 June 2001 at 1200 UTC (Fig. 2c), the Genoa cyclone is removed by a föhn knee associated with the surface pressure gradient, which is favorable to large cyclonic curvature of the mistral at the exit of the Rhône Valley. The situation on 23 June 2001 at 0000 UTC is similar to that on 22 June 2001 at 0000 UTC (Fig. 2d). This mistral event differs significantly from that of 28 June 2001 described in Drobinski et al. (2005) because the weakness of the Genoa cyclone. The comparatively small induced pressure gradient between the windward side and the leeward side of the Alps generates weaker winds, which may explain why the sea breeze can break through on that day.

\section{b. Flow structure in the Rhône Valley}

\section{1) NeAR-Surface flow PATtern}

At 0900 UTC, the flow pattern at the exit of the Rhône Valley is shown in Fig. 3, which displays (left) measured and (right) simulated surface temperature and wind fields [the temperature is represented instead of the potential temperature since the surface pressure is only measured at very few stations, but only the measurements made below $500 \mathrm{~m}$ above sea level (ASL) are shown]. Figure 3a shows that the mistral blows over 

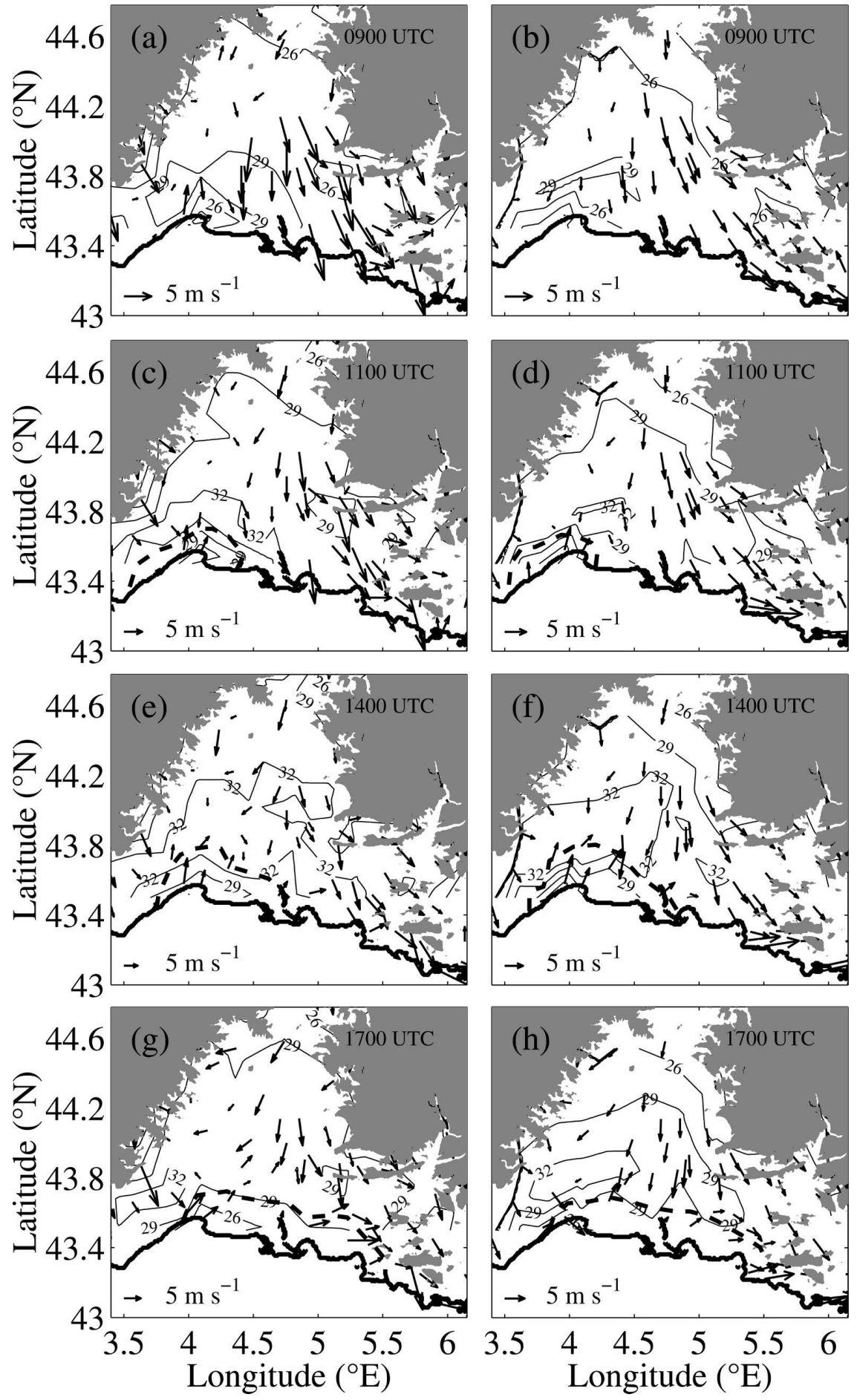

FIG. 3. The 10-m wind and 2-m temperature fields from (left) meteorological surface stations and (right) Méso-NH simulations at (a), (b) 0900, (c), (d) 1100, (e), (f) 1400, and (g), (h) 1700 UTC 22 Jun 2001. The simulated data used for this figure correspond to the data interpolated at the locations of the surface stations. The topography mask corresponds to topographical elements higher than $500 \mathrm{~m}$ ASL. The arrows indicate the wind direction and their scale indicates the intensity. The isolines indicate the temperature. Contour interval is $3^{\circ} \mathrm{C}$ from $23^{\circ}$ to $38^{\circ} \mathrm{C}$. The sea-breeze front location is indicated by a thick dashed line. 
the nearly entire area, except for two regions: on the western side of the domain (longitude lower than $4^{\circ} \mathrm{E}$ ) and on the eastern side of the domain (longitude greater than $5.6^{\circ} \mathrm{E}$ ). Indeed, these are two sheltered area in the wakes trailing downstream the Massif Central and the western Alps, respectively. The mistral brings cold and dry continental air (Bastin et al. 2005a) and inhibits temperature rise. The temperature gradient between sea and land is thus damped and contributes to delay the sea-breeze onset in the region where the mistral blows. On the contrary, in the sheltered area, the temperature naturally increases with radiative heating (in the sheltered area, the temperature increases from $28^{\circ}$ to $30^{\circ} \mathrm{C}$ ), and thus the sea breeze commences at a time expected in pure sea-breeze events (Bastin et al. 2005b; Bastin and Drobinski 2005a). The presence or absence of the mistral blowing in some regions of the investigated target area contributes to the time and space inhomogeneity of the sea breeze, whereas in pure sea-breeze events, the sea-breeze onset occurs at the nearly same time everywhere along the coastline [see examples for the 25 and 26 June 2001 sea-breeze events in Bastin et al. (2005b)]. One can also note the asymmetry of the mistral structure in the Rhône Valley. The mistral sticks to the eastern flank of the Rhône Valley whereas it detaches from the Massif Central after the maximum constriction near Valence (see Fig. 1b), when it takes a cyclonic curvature due to the Genoa cyclone (or at least to the leeside trough downstream the Alps).

At 1100 UTC (Fig. 3c), the data show a surface temperature gradient near the coastline on the sheltered western region of the target area (longitude $\simeq 4^{\circ} \mathrm{E}$ ) (the temperature increases from $28^{\circ}$ to $32^{\circ} \mathrm{C}$ ). The sea breeze penetrates inland over a small horizontal range. The sea-breeze front location is indicated by a thick dashed line. The location of the sea-breeze front is determined by associating the location of the maximum temperature and the area where the wind reverses from the south (sea-breeze flow) to the north (mistral flow). One can also notice that the northwesterly mistral flow descends the slope of the Massif Central in its southern part whereas a wake trailing downstream the Massif Central, in the north part of the domain, is associated with very weak winds. The mistral is bounded by the eastern flank of the Rhône Valley to the east and by the Massif Central wake to the west at about $4.5^{\circ} \mathrm{E}$ (Jiang et al. 2003). In the region where the mistral blows, the sea breeze cannot penetrate inland.

At 1400 UTC (Fig. 3e), the region where the sea breeze penetrates now extends farther to the east. In the western side of the domain, the sea-breeze front has progressed inland. The maximum penetration of the sea breeze is observed at about $43.85^{\circ} \mathrm{N}$ (between $3.8^{\circ}$ and $4.3^{\circ} \mathrm{E}$ ). Between 1400 and 1700 UTC, the seabreeze front progresses inland in the center of the Rhône Valley (longitude $\simeq 4.5^{\circ} \mathrm{E}$ ). The front line has "moved" eastward and at 1700 UTC (Fig. 3g), the sea breeze does not penetrate inland anymore in the western side of the target area, downstream of the Massif Central. At 1700 UTC, the sea breeze blows in the Marseille area where it takes a westerly direction because of the coastline shape (Bastin and Drobinski 2005a,b) and because it combines with the mistral. The observations indicate a large region in the Rhône Valley (between $43.7^{\circ}$ and $44.4^{\circ} \mathrm{N}$ ) where there is no temperature gradient and where the sea breeze and the mistral collide (at $43.8^{\circ} \mathrm{N}$ ).

\section{2) Vertical structure}

The radiosonde launched from Lyon on 22 June 2001 at 1100 UTC shows the synoptic northwesterly flow impinging on the Alps (Fig. 4, upper row). Below the potential temperature inversion at $1.6 \mathrm{~km}$, the mistral blows at about $4.2 \mathrm{~m} \mathrm{~s}^{-1}$ with a more west-northwest direction (about $310^{\circ}$ ). Between 1.6 and $2.4 \mathrm{~km}$ ASL, the wind speed increases: it is about $10 \mathrm{~m} \mathrm{~s}^{-1}$ at $2-\mathrm{km}$ height and takes a constant value of about $13 \mathrm{~m} \mathrm{~s}^{-1}$ above about $2.5-\mathrm{km}$ height. The radiosounding launched from Nîmes at 1100 UTC (Fig. 4, lower row) shows a deeper PBL since the potential temperature inversion height is about $2.0 \mathrm{~km}$. Above the PBL the wind speed and direction take constant values equal to those measured with the radiosounding launched from Lyon, that is, about $13 \mathrm{~m} \mathrm{~s}^{-1}$ and $315^{\circ}$, respectively. Below the PBL top, the wind is slightly weaker than the upstream wind speed in Lyon $\left(2.5 \mathrm{~m} \mathrm{~s}^{-1}\right.$ at Nîmes versus $4.2 \mathrm{~m} \mathrm{~s}^{-1}$ at Lyon) ands veers to the northeast below 500-m height. Looking at Fig. 3c, Nîmes is located in the Massif Central wake, which explains the weakness of the wind speed.

Figures 5 and 6 display the time series of the vertical profiles of the horizontal wind speed and direction measured by the UHF wind profilers (top row) and simulated by Méso-NH (bottom row) on 22 June 2001 at Saint Chamas (STC) and Marignane (MAR), and Marseille (MRS) and Aix-en-Provence (AIX), respectively (see locations of the UHF wind profilers in Fig. 1c). The UHF wind profilers give a detailed insight on the alternation between the sea breeze and the mistral flow. At Saint Chamas, the onset and breakdown of the sea breeze are illustrated by the UHF wind profiler data (Figs. 5a and 5b). The UHF wind measurements show that the mistral blows from the northwest until about 1530 UTC. Its intensity decreases at sunrise from about $10 \mathrm{~m} \mathrm{~s}^{-1}$ down to $5 \mathrm{~m} \mathrm{~s}^{-1}$ due to the convection 

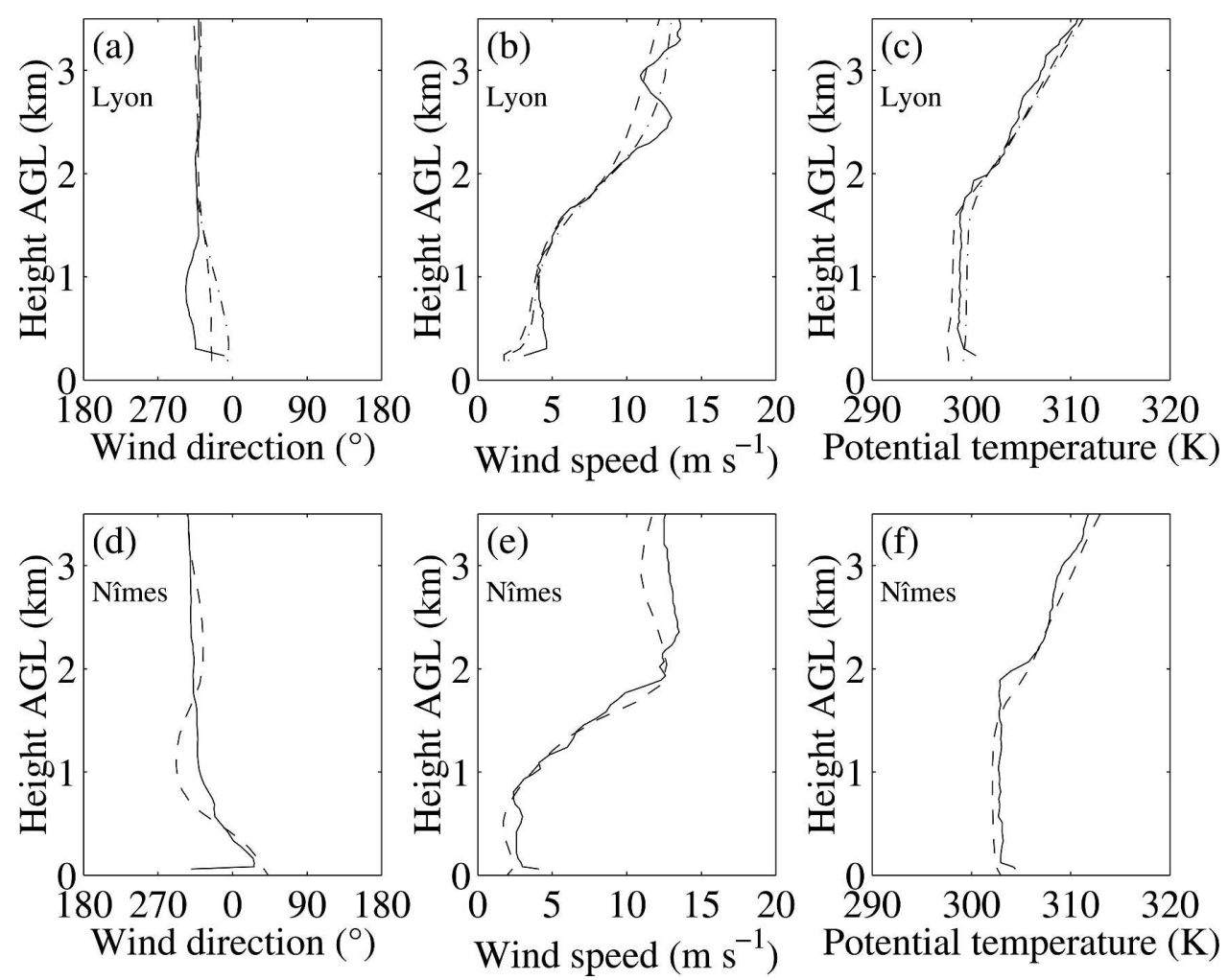

FIG. 4. Vertical profiles of (a), (d) wind direction, (b), (e) wind speed, and (c), (f) potential temperature from the 1100 UTC radiosoundings launched from (top) Lyon and (bottom) Nîmes (solid line) on 22 Jun 2001. The 1100 and 1700 UTC simulated profiles at Lyon are displayed with dashed and dash-dot lines, respectively, in the top row. The 1100 UTC simulated profile at Nîmes is displayed with dashed line in the lower row.

that increases friction near the surface. At 1530 UTC, the low-level wind veers from the northwest to the west-southwest, indicating the sea breeze onset over Saint Chamas. The vertical extent of the sea breeze evolves with time: the sea breeze is about $900 \mathrm{~m}$ deep at 1600 UTC and $700 \mathrm{~m}$ deep at 1800 UTC. The sea breeze does not blow after 2200 UTC since after 2200 UTC, the wind turns to the north. At Marignane located southeast of Saint Chamas, the UHF data are unreliable near the surface and above $1.7-\mathrm{km}$ height (Figs. 5e and 5f). However, the reliable measurements show the same time evolution as in Saint Chamas and take very similar values, even though the estimation of the accurate onset time for the sea breeze is more difficult in the absence of near-surface measurements. At Marseille (Figs. 6a and 6b) and Aix-en-Provence (Figs. 6e and 6f), the time evolution of the UHF wind profiler data differs from that observed in Saint Chamas and Marignane (which are rural/peri-urban areas). At Marseille, the wind veers from the northwest to the west at about 1530 UTC. Over Marseille the sea breeze usually takes a southwesterly direction below $500 \mathrm{~m}$ (Bastin and
Drobinski 2005a,b; Lemonsu et al. 2005) and the mistral a northwesterly direction (Drobinski et al. 2005), so in contrast to what occurs at Saint Chamas and Marignane where the sea breeze and the mistral have opposite direction and collide at a well-marked front, the sea breeze and the mistral combine near Marseille. This results in a higher wind speed over Marseille than that measured at Saint Chamas and Marignane, located closer to the Rhône Valley axis. During the day the sea-breeze flow hardly reaches Aix-en-Provence, located $30 \mathrm{~km}$ north of Marseille. The UHF wind direction does not show evidence of significant direction shift despite a weakening of the mistral flow in the evening of 22 June 2001. But the UHF of Aix-enProvence is located farther inland than the others UHF, and, if the sea breeze reaches Aix-en-Provence, it is likely that the depth of the sea breeze would be inferior to the depth of the sea breeze in Marseille or Saint Chamas. So, the absence of near-surface measurements does not allow one to capture the sea-breeze flow if only it exists.

The spatial variability of the vertical structure of the 


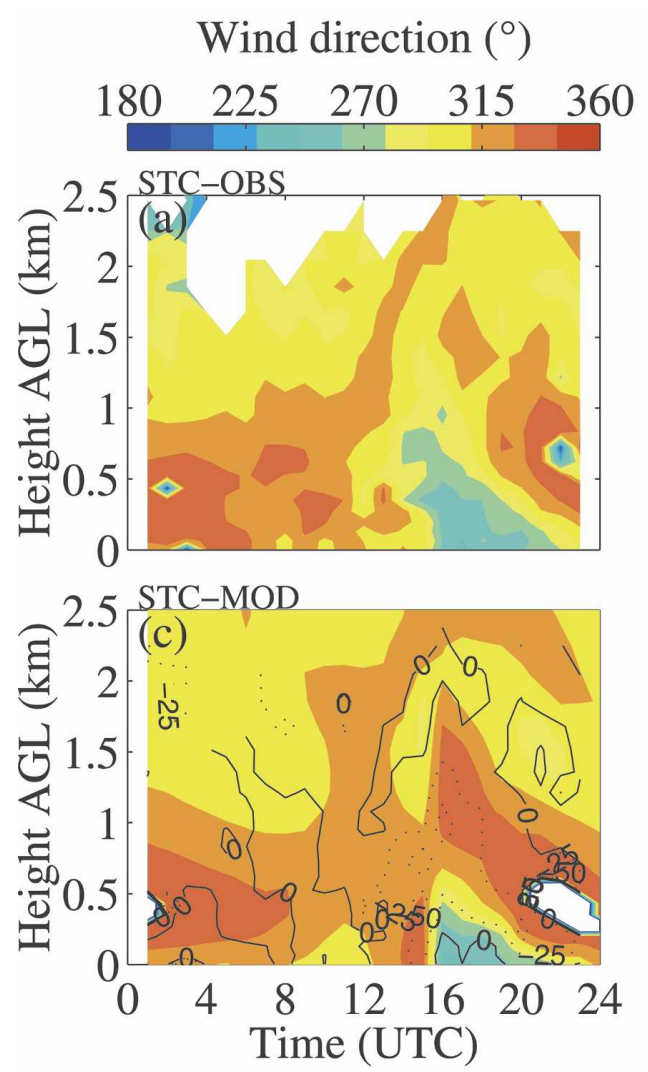

Wind speed $\left(\mathrm{m} \mathrm{s}^{-1}\right)$
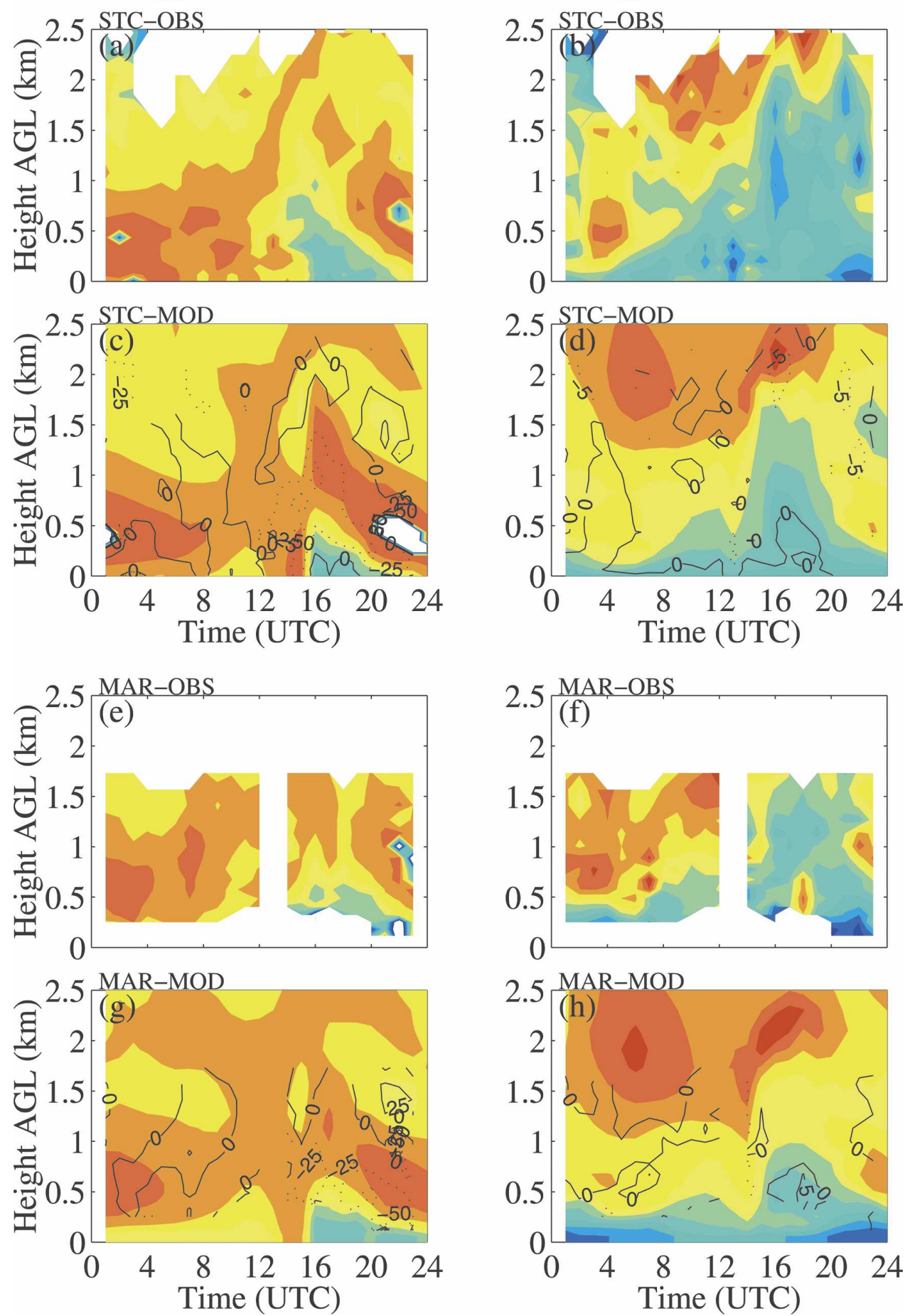

FIG. 5. Time vs height plot of (left) wind direction and (right) wind speed as (top) measured by the UHF wind profiler and (bottom) simulated with Méso-NH on 22 Jun 2001 at (a)-(d) Saint Chamas (STC) and (e)-(h) Marignane (MAR) (see STC and MAR in Fig. 1c). White color corresponds to missing data. Abbreviations are observation (OBS) and model (MOD). The contours in (c) and (g), and (d) and (h), correspond to the difference between the simulated and measured wind speed and direction, respectively. The contour intervals (CIs) are $5 \mathrm{~m} \mathrm{~s}^{-1}$ and $25^{\circ}$, respectively. 


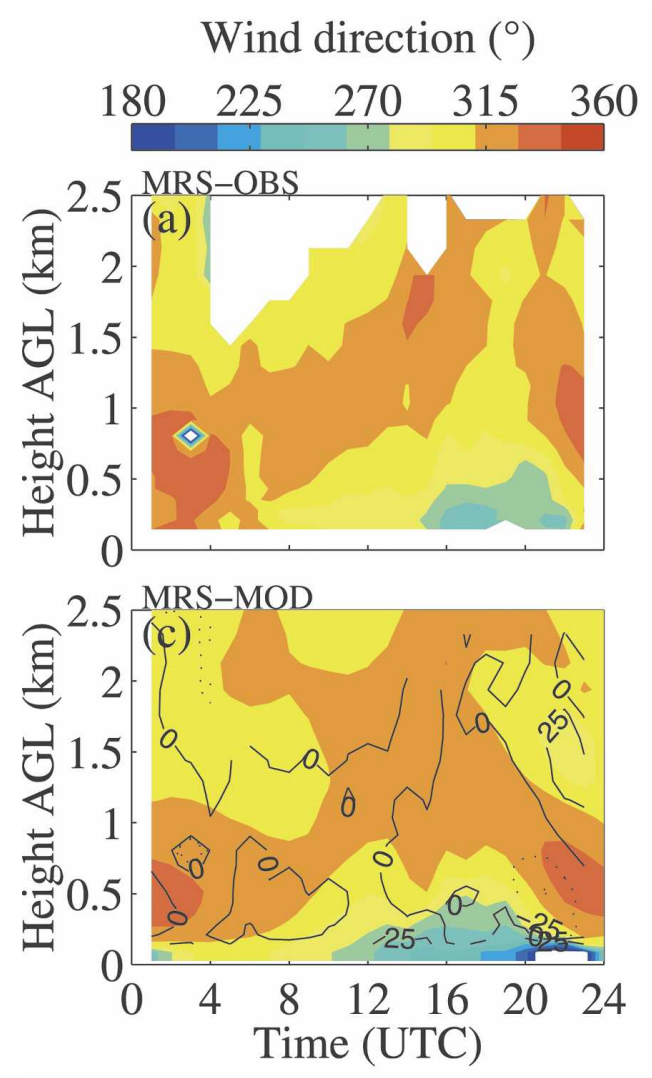

Wind speed $\left(\mathrm{m} \mathrm{s}^{-1}\right)$
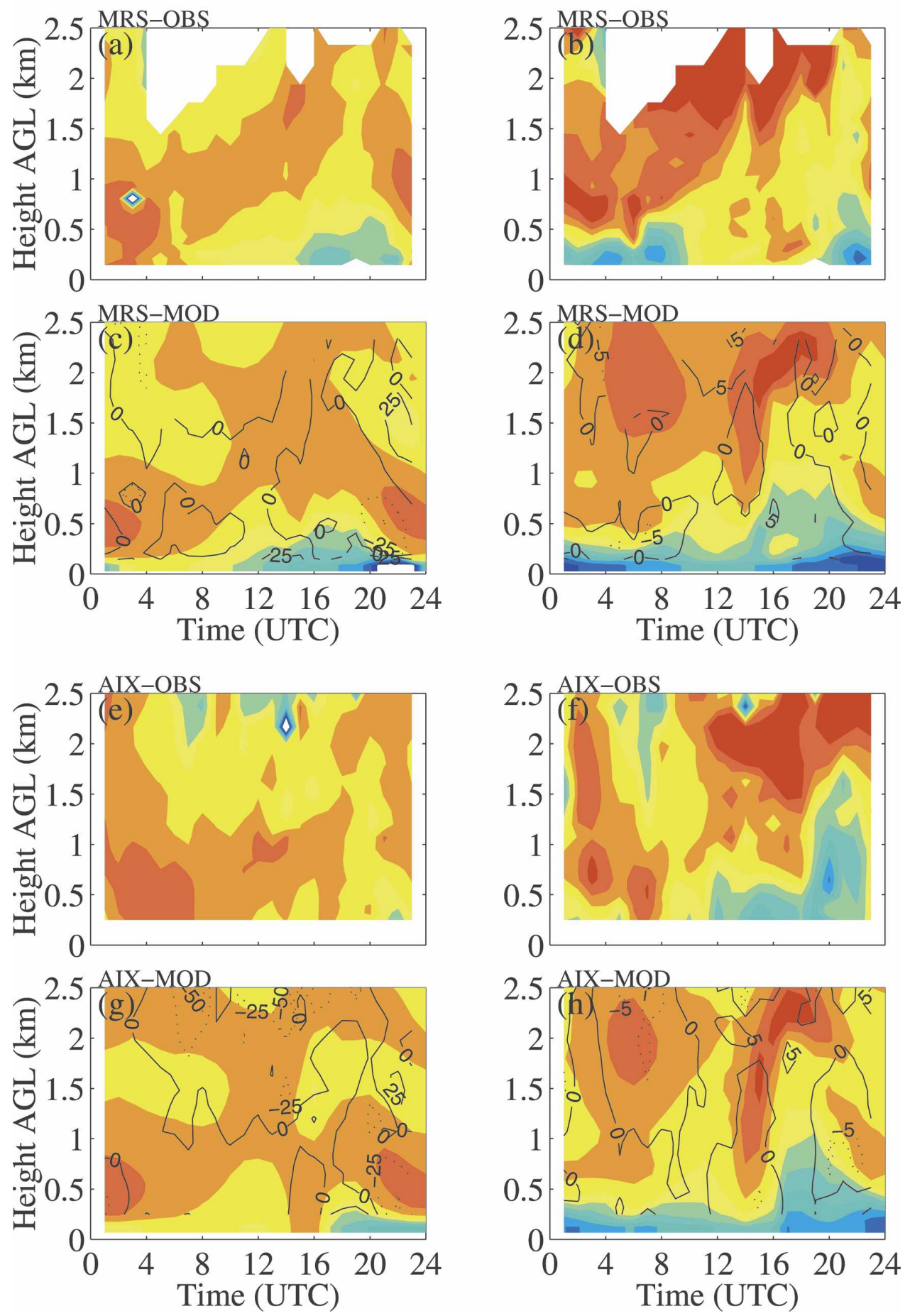

FIG. 6. Same as Fig. 5 but at (a)-(d) Marseille (MRS) and (e)-(h) Aix-en-Provence (AIX) (see MRS and AIX in Fig. 1c). 
sea breeze and mistral flow is accessible with the wind measurements by the airborne Doppler lidar WIND. Figure 7 displays the wind field measured along leg B-A by the airborne Doppler lidar WIND (Figs. 7a and $7 b)$ and the corresponding simulated field at 1700 UTC (Figs. 7c and 7d). Since the vertical resolution is $250 \mathrm{~m}$, the Doppler lidar observations do not allow us to document the near-surface flow, and it is thus difficult to distinguish the sea-breeze circulation. However, one can see that the near-surface flow has a more pronounced westerly component between $43.4^{\circ}$ and $43.8^{\circ} \mathrm{N}$ (orange) than north of $43.8^{\circ} \mathrm{N}$ where the flow blows from the north (red and blue). This figure shows that a horizontal shear of the wind appears at $43.8^{\circ} \mathrm{N}$ up to $1.5-\mathrm{km}$ height, with the wind speed decreasing suddenly from 11-12 $\mathrm{m} \mathrm{s}^{-1}$ north of this latitude to about 6-8 $\mathrm{m} \mathrm{s}^{-1}$. Latitude $43.8^{\circ} \mathrm{N}$ is the location of the sea-breeze front detected with the surface stations at 1700 UTC in Fig. 3. So, even though the wind direction is northwesterly, the sea-breeze flow also affects the mistral in altitude.

\section{Model validation}

A thorough validation of the model is made in order to rely on the model outputs to analyze the processes governing the unsteady and inhomogeneous penetration of the sea breeze in presence of the mistral. In general, Méso-NH reproduces accurately the flow structure except for the western Alps wake located too far to the east (longitude greater than $6^{\circ} \mathrm{E}$ ). The surface wind and temperature fields are evaluated by comparing the measured $10-\mathrm{m}$ horizontal wind components and 2-m temperature to their simulated counterparts interpolated at the location of the meteorological surface stations (Fig. 3, right column). The surface wind and temperature fields are accurately simulated with Méso-NH, despite the slight bias in temperature in the northern part of the Rhône Valley (up to $2 \mathrm{~K}$, see Fig. 3). Quantitatively, Fig. 8 shows the histograms of the difference between the hourly simulated and measured $10-\mathrm{m}$ zonal and meridional wind components and 2-m temperature during the 24-h period of 22 June 2001. The measured $10-\mathrm{m}$ wind speed and $2-\mathrm{m}$ temperature accuracies are $1 \mathrm{~m} \mathrm{~s}^{-1}$ and about $0.1 \mathrm{~K}$, respectively. The bias between Méso-NH and the measured wind speed is $-0.14 \mathrm{~m} \mathrm{~s}^{-1}$ for the two horizontal components, which is thus nonsignificant. The standard deviation is also small considering the accuracy of the wind observations. As for the temperature, the largest discrepancies are found in the steep orography regions where the height of the topography is not accurately represented in the model and at night when numerical diffusion slightly deteriorates the simulation of the near-surface temperature and the katabatic flows. The average temperature bias is in part due to the underprediction of the 2-m temperature near Valence at the maximum constriction of the Rhône Valley.

For the evaluation of the simulated vertical structure of the sea breeze and the mistral, comparisons are made with the radiosoundings (Fig. 4), the UHF wind profilers (Figs. 5 and 6), and the airborne Doppler lidar WIND (Fig. 7). The simulated 1100 UTC sounding over Lyon is extracted from Méso-NH domain 1 and is plotted with dashed line in Fig. 4. Méso-NH is on average performing well (at most $2 \mathrm{~m} \mathrm{~s}^{-1}$ difference, less than $20^{\circ}$ and $1-\mathrm{K}$ differences on average for the wind direction and potential temperature, respectively). It underestimates the near-surface superadiabatic potential temperature profile due to the coarser resolution of domain 1 and to the underestimation of the surface temperature in the north of the domain (see Fig. 3). It slightly underestimates the potential temperature inversion (1.5 km versus observed $1.6 \mathrm{~km}$ ), and the flow below the inversion is more aligned with the Rhône Valley axis (north-south orientation). The simulated vertical profile at 1700 UTC (dash-dot line) shows that the upstream conditions do not vary much between 1100 and 1700 UTC: the PBL potential temperature slightly increases with time (it is $297.5 \mathrm{~K}$ at 1100 UTC and $299.5 \mathrm{~K}$ at $1700 \mathrm{UTC}$ ) but the PBL depth remains similar; the wind slightly veers from the northnorthwest to the north below the potential temperature inversion height and the wind speed remains constant. The vertical profile obtained from the radiosounding launched from Nîmes at 1100 UTC is also accurately reproduced by the model (domain 2) with at most 2 $\mathrm{m} \mathrm{s}^{-1}$ difference, less than $20^{\circ}$ and $1-\mathrm{K}$ differences on average for the wind direction and potential temperature, respectively. At Nîmes also the potential temperature inversion height is slightly underestimated by the model (1.8 km versus observed $2.0 \mathrm{~km})$. The comparison of the wind speed and direction as a function of time and height measured by the UHF wind profilers and simulated with Méso-NH is also accurate (Figs. 5 and 6). The average difference between the measurements (having an accuracy of 1-2 $\mathrm{m} \mathrm{s}^{-1}$ ) and the simulation does not exceed $3 \mathrm{~m} \mathrm{~s}^{-1}$ and $20^{\circ}$ for wind speed and direction, respectively. The largest discrepancies (which can reach $5 \mathrm{~m} \mathrm{~s}^{-1}$ and $50^{\circ}$ for wind speed and direction, respectively, at Marignane and Aix-enProvence, particularly) are often found during fast transitions when a slight time lag in the simulation generates large differences. However the differences are very limited in time and space and thus do not question the quality of the simulation. Finally, Fig. 7 shows that 

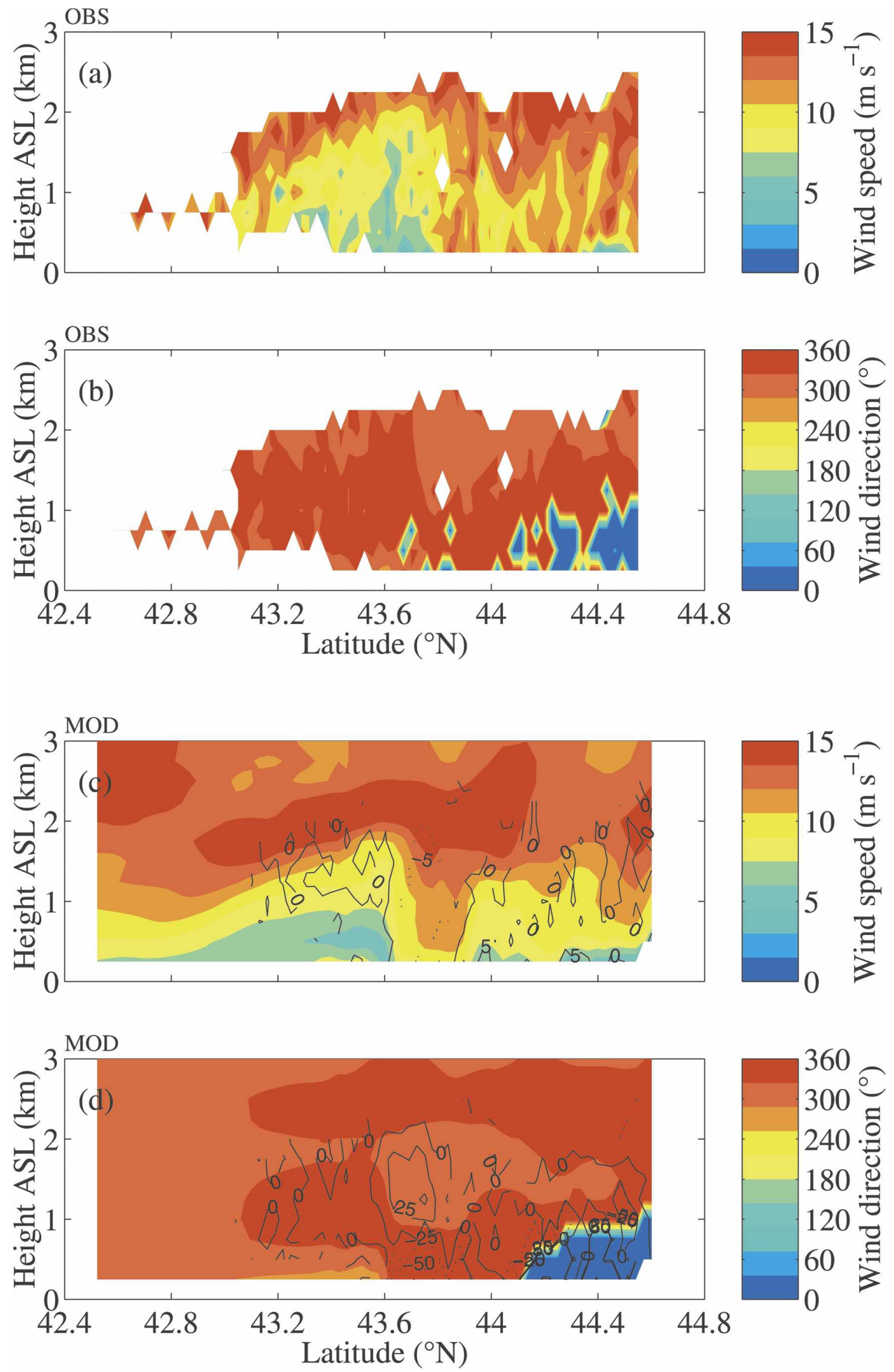

FIG. 7. Horizontal wind field along leg B-A shown in Fig. 1b. (a) The wind speed and (b) direction measurements by the airborne Doppler lidar WIND between 1635 and 1653 UTC, and (c) the wind speed and (d) direction simulated with Méso-NH at 1700 UTC. White color corresponds to missing data and the acronyms OBS and MOD stand for observation and model, respectively. The contours in (c) and (d) correspond to the difference between the simulated and measured wind speed (CI $5 \mathrm{~m} \mathrm{~s}^{-1}$ ) and direction $\left(\mathrm{CI} 25^{\circ}\right)$, respectively. 

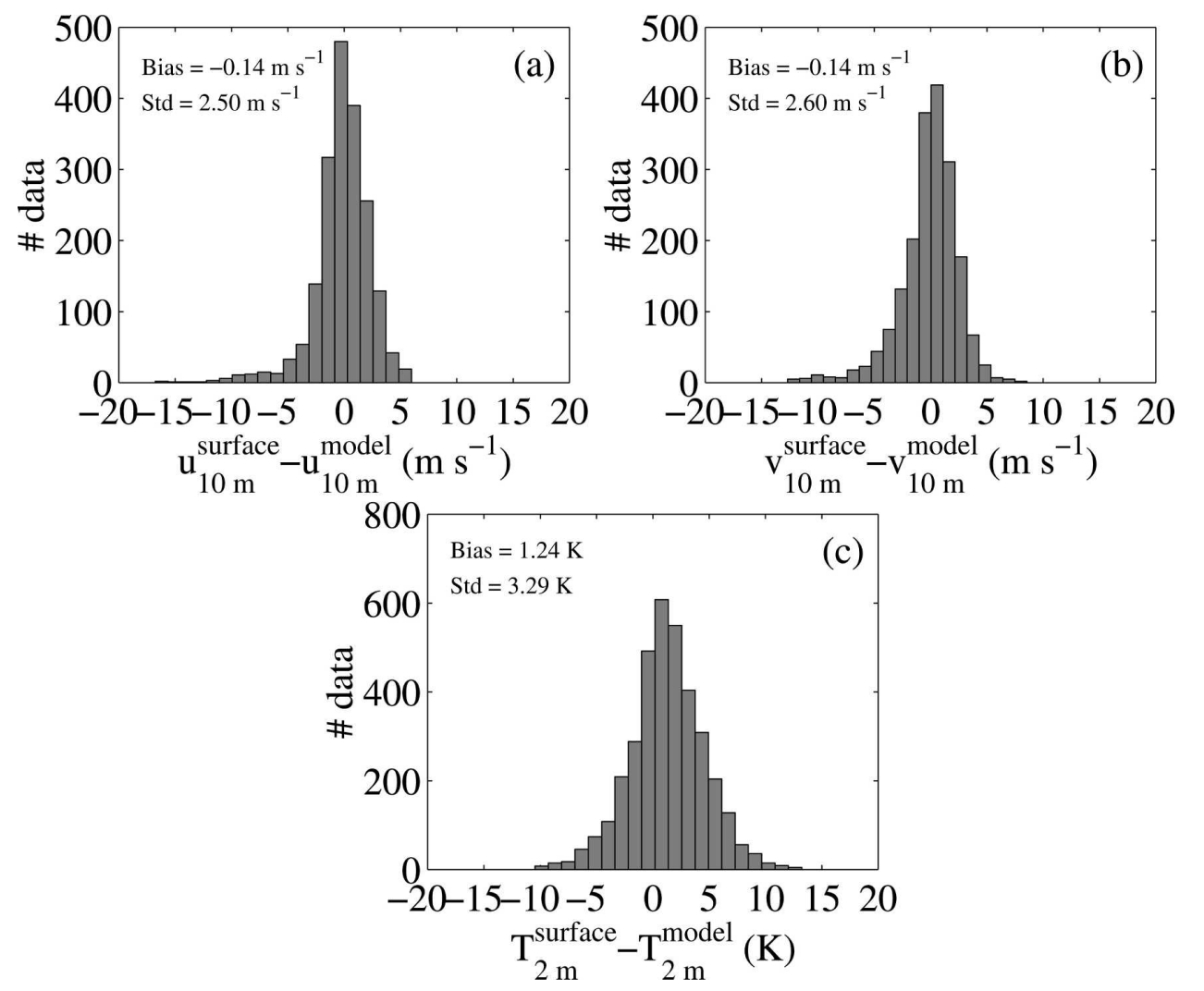

FIG. 8. Histograms of the difference between the hourly simulated and measured 10-m (a) zonal and (b) meridional wind components and (c) 2-m temperature during the 24-h period of 22 Jun 2001. The measured 10-m wind speed and 2-m temperature accuracies are $1 \mathrm{~m} \mathrm{~s}^{-1}$ and about $0.1 \mathrm{~K}$, respectively.

Méso-NH reproduces well the vertical structure of the flow along the section B-A flown by the airborne Doppler lidar. The location of the simulated sea-breeze front is very slightly shifted to the south by about $10 \mathrm{~km}$ with respect to the observations $\left(43.7^{\circ} \mathrm{N}\right.$ in the simulation versus $43.8^{\circ} \mathrm{N}$ in the observations) (the largest discrepancies are thus found in this area). The observed mistral flow is also slightly stronger below $1.5 \mathrm{~km}$ AGL than in the simulation (the difference is about $2 \mathrm{~m} \mathrm{~s}^{-1}$ for a measurement accuracy of about $1 \mathrm{~m} \mathrm{~s}^{-1}$ ).

In the following, we consider that the Méso-NH simulation is validated and is used to provide the threedimensional environment necessary for the interpretation of the measurements.

\section{Origin of the unsteadiness of mistral-sea-breeze interaction}

Despite very similar conditions upstream of the Alps (see the similar vertical profiles at Lyon at 1100 and 1700 UTC in Fig. 4) and upstream of the Massif Central (not shown), Fig. 9, which displays a horizontal cross section of the simulated wind field at $400 \mathrm{~m} \mathrm{AGL}$ in the larger domain (domain 1 in Fig. 1b), shows that the flow structure in the Rhône Valley delta, south of the maximum constriction near Valence, differs significantly between 1100 and 1700 UTC. Indeed, at 1100 UTC, the northwesterly synoptic wind impinges on the Alpine ridge near Lyon and is deflected in the Rhône Valley where it veers to the north because of channeling and is accelerated due to valley constriction (Drobinski et al. 2001a). After the maximum constriction near Valence, the Rhône Valley can be split into two regions: (i) the western side of the Rhône Valley near the Massif Central, where the wind is weak and is associated with the wake trailing downstream the Massif Central and which defines the western boundary of the mistral (Jiang et al. 2003). South of the Massif Central wake, the Tramontane (considered as the companion of the mistral since they have the same synoptic origin and often blow simultaneously) blows through the Garonne gap between the Massif Central and the Pyrénées (Fig. 1a) (Georgelin and Richard 1996; Drobinski et al. 2001b); (ii) the eastern side of the Rhône Valley near the western Alps, in which the mistral blows and sticks to the valley flank until the flow detaches from the topography at $6^{\circ} \mathrm{E}$ lon- 

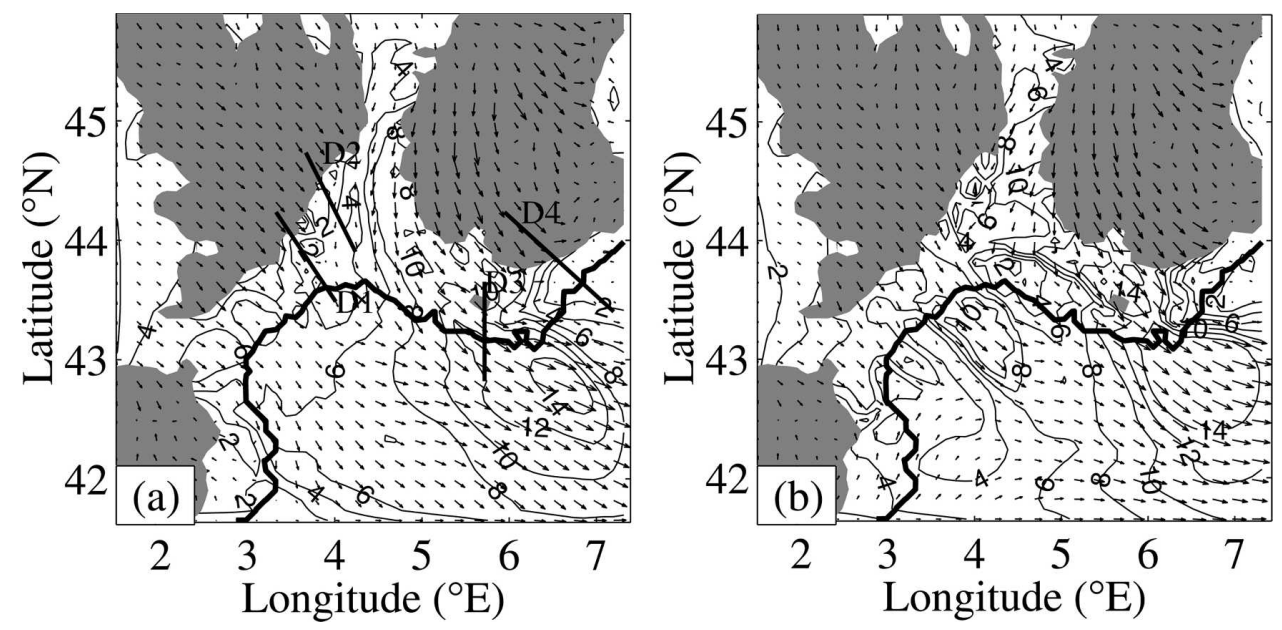

FIG. 9. Simulated 400-m AGL horizontal wind over the Rhône Valley delta at (a) 1100 and (b) 1700 UTC 22 Jun 2001 from model domain 1. Contour interval is $2 \mathrm{~m} \mathrm{~s}^{-1}$ from 0 to $14 \mathrm{~m} \mathrm{~s}^{-1}$. Lines D1, D2, D3, and D4 in (a) show the location of the vertical sections studied in section 5.

gitude. Flow separation from the sidewall of the western Alps occurs farther to the east in comparison with the 28 June 2001 mistral event (Drobinski et al. 2005). One can note the acceleration of the mistral as it reaches the Mediterranean Sea because of roughness reduction. At 1700 UTC, Fig. 9b shows that the flow structure in the Rhône Valley delta, south of the maximum constriction near Valence, differs significantly from the flow structure at 1100 UTC. The sea breeze blows onshore over a region that does not extend very far inland. Within the sea-breeze flow, the wind speed is weaker than in the mistral flow and its direction varies depending on the local coastline orientation and on the combination with the mistral. Downstream of the Massif Central, one can note two different regions: (i) south of the Rhône Valley maximum constriction, the Massif Central wake with weak wind is similar to that at 1100 UTC but with a smaller spatial extent; (ii) south of the Massif Central (about $3.2^{\circ} \mathrm{E}$ and $43.5^{\circ} \mathrm{N}$ ), the northwesterly impinging air flows over the Massif Central where the maximum crest height is about 1000-m height. In the eastern side of the Rhône Valley, the mistral sticks to the flank of the valley. In contrast to the situation at 1100 UTC, a sharp deceleration of the wind from $10-11 \mathrm{~m} \mathrm{~s}^{-1}$ down to $6-7 \mathrm{~m} \mathrm{~s}^{-1}$ is visible between about $44.0^{\circ}$ and $44.2^{\circ} \mathrm{N}$, as shown in Fig. 7 .

\section{a. Western side of the Rhône Valley}

Figure 10 shows a vertical cross section of the alongsection wind field $\left(v_{h}-w\right)$ and isentropes transecting the southern part of the Massif Central at 0600, 1100, 1400, and 1700 UTC. The arrows represent the wind vector $\left(v_{h}, w\right)$ where $v_{h}$ is the along-section horizontal velocity component and $w$ the vertical wind component. The line D1, along which the section is made, is indicated in Fig. 9a. Downstream of the Massif Central, Fig. 10 shows that at 0600 UTC, the airflow that descends the Massif Central is blocked by a stagnant cold air pool at the foothill of the massif. The pressure difference between the upwind and lee sides of the Massif Central, which forces the mistral flow over the ridge, is about $1.8 \mathrm{hPa}$. At $0900 \mathrm{UTC}$, the mean sea level pressure field, displayed in Fig. 11, still shows no pressure gradient across the shoreline in the Rhône Valley (Fig. 11a). As the sun rises, radiative heating induces convective mixing, which in turn erodes the cold air pool. Convective activity contributes to decrease the mean sea level pressure near the shore on the western side of the Rhône Valley (Fig. 11b). Convection is facilitated by the fact that this area is located within the Massif Central wake similarly to the 28 June 2001 mistral case (Drobinski et al. 2005), so the mistral does not contribute to the stabilization of the near-surface layer. Convection has two antagonist effects: (i) it promotes seabreeze circulation due to cross-shoreline pressure gradient and (ii) contributes to reinforce the pressure difference across the Massif Central ridge and thus intensify the descending mistral flow. Indeed the pressure difference between the upwind and lee sides of the Massif Central is about $3 \mathrm{hPa}$ at 1100 and 1400 UTC, which corresponds to a pressure difference increase of about $1.2 \mathrm{hPa}$ between 0600 UTC and midday. Looking at Figs. $11 \mathrm{~b}$ and $11 \mathrm{c}$, one can note that the crossshoreline pressure difference is nearly zero at 0900 UTC and is about $0.9 \mathrm{hPa}$ at 1100 and 1400 UTC. The deepening of the surface heat low in the southwestern 


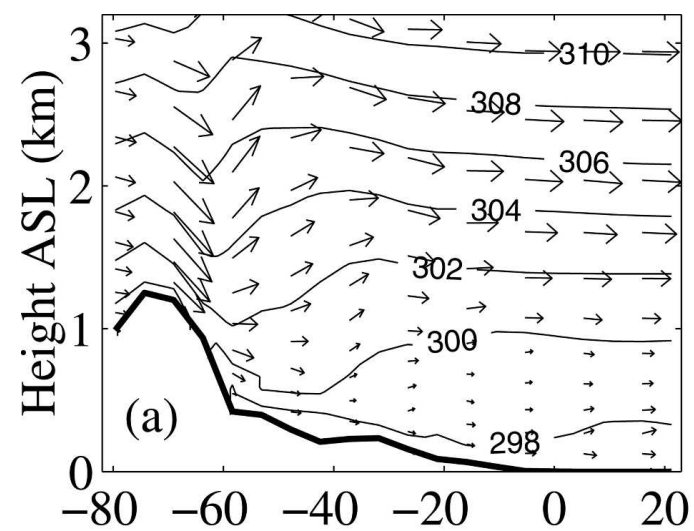

Distance to the coastline $(\mathrm{km})$

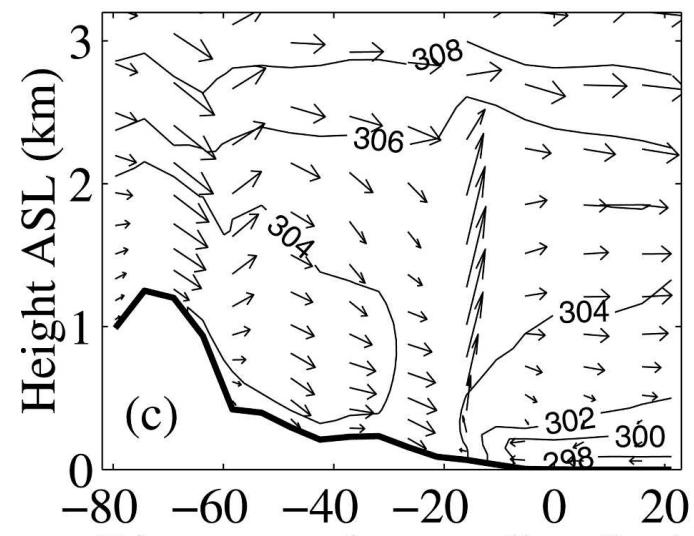

Distance to the coastline $(\mathrm{km})$
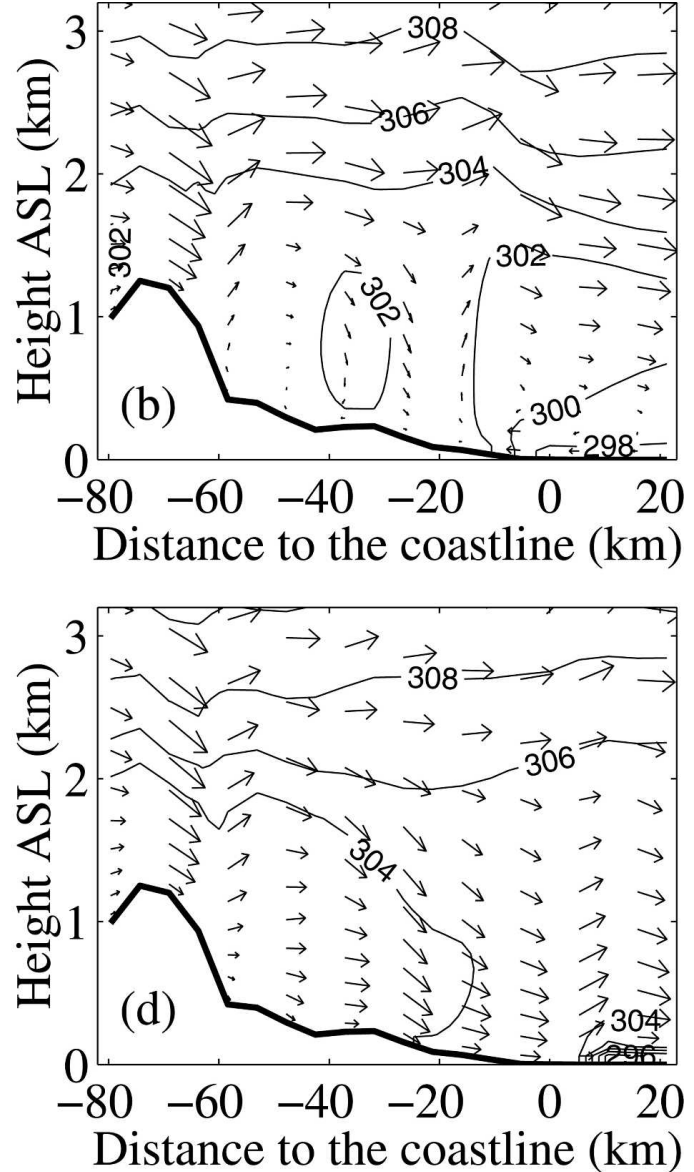

FIG. 10. Vertical cross section of the $v_{h}-w$ wind components ( $v_{h}$ is the along-section horizontal wind component and $w$ the vertical wind component multiplied by a factor 10 for legibility) and the isentropes along section D1 transecting the western part of the Massif Central (see Fig. 9a) at (a) 0600, (b) 1100, (c) 1400, and (d) 1700 UTC 22 Jun 2001. The "negative distance" indicates the distance to the coastline over land, whereas the "positive distance" indicates the distance to the coastline over sea.

area at the foothill of the Massif Central is thus the main cause of the increase of the pressure difference between the upstream and downstream sides of the Massif Central. At 1100 UTC, the still-weak mistral flow is disrupted by convection as it descends along the slope (see Fig. 10b between 40 and $60 \mathrm{~km}$ onshore) and forms a vortex similar to a lee rotor. Farther to the south a secondary updraft is produced at the sea-breeze front located at about $43.6^{\circ} \mathrm{N}$ and $4^{\circ} \mathrm{E}$ (i.e., $10 \mathrm{~km}$ onshore in Fig. 10b) where an adverse pressure gradient is found (see the 1012.9-hPa isoline in Fig. 11b). Figure 12a displays the same horizontal cross section as Fig. 9a but for the simulated turbulent kinetic energy (TKE) field. The contribution of convection to TKE is less than $1 \mathrm{~m}^{2} \mathrm{~s}^{-3}$ as also shown in Bastin and Drobinski (2005a) for the 25 June 2001 pure sea-breeze event. The regions where the TKE exceeds this value are regions where mechanical TKE also contributes. We clearly see on the western side of the Rhône Valley an area of particularly large TKE values, which corresponds to the area where the mistral and the sea breeze collide near the shore. At 1400 UTC, the response of the atmospheric flow due to the pressure difference increase between the upstream and downstream sides of the Massif Central leads to the strengthening of the mistral flow and allows the descending mistral flow to penetrate down to the surface (Fig. 10c). A strong updraft is visible at the sea-breeze front since the adverse pressure gradient generates boundary layer separation. The sea breeze has not penetrated much farther inland but its intensity has increased (from 4 to $6 \mathrm{~m} \mathrm{~s}^{-1}$ ) due to the descending flow that has reinforced with time (it blows at about $9 \mathrm{~m} \mathrm{~s}^{-1}$ at 1400 UTC), enhancing frontogenesis (Arritt 1993). A sea breeze "head" forms at the front with strong upward motions up to $2 \mathrm{~km}$ ASL. The mistral is thus lifted up and goes on blowing above the 

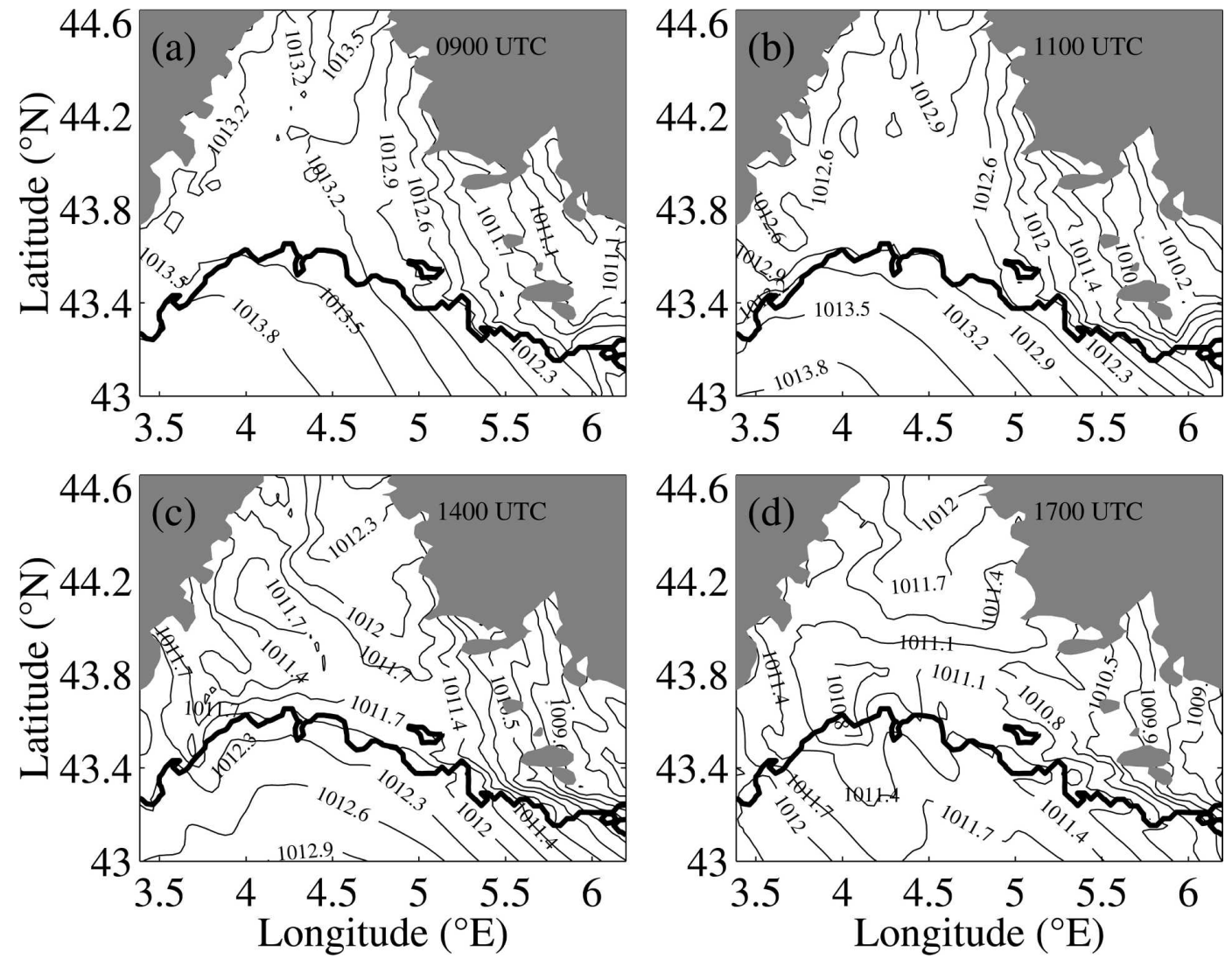

FIG. 11. Simulated mean sea level pressure (hPa) in the Rhône Valley delta at (a) 0900, (b) 1100, (c) 1400, and (d) 1700 UTC 22 Jun 2001 from model domain 2.

sea-breeze flow. The mistral acts as a rigid lid that prevents the vertical extension of the sea breeze. Indeed, on 22 June 2001, the sea breeze is only 500-700 m deep, whereas on 25 and 26 June 2001, the sea breeze extends up to about $1200 \mathrm{~m}$ (Bastin et al. 2005b; Bastin and Drobinski 2005a). At 1700 UTC, the pressure difference between the upstream and downstream sides of the Massif Central increases up to about $4 \mathrm{hPa}$, leading
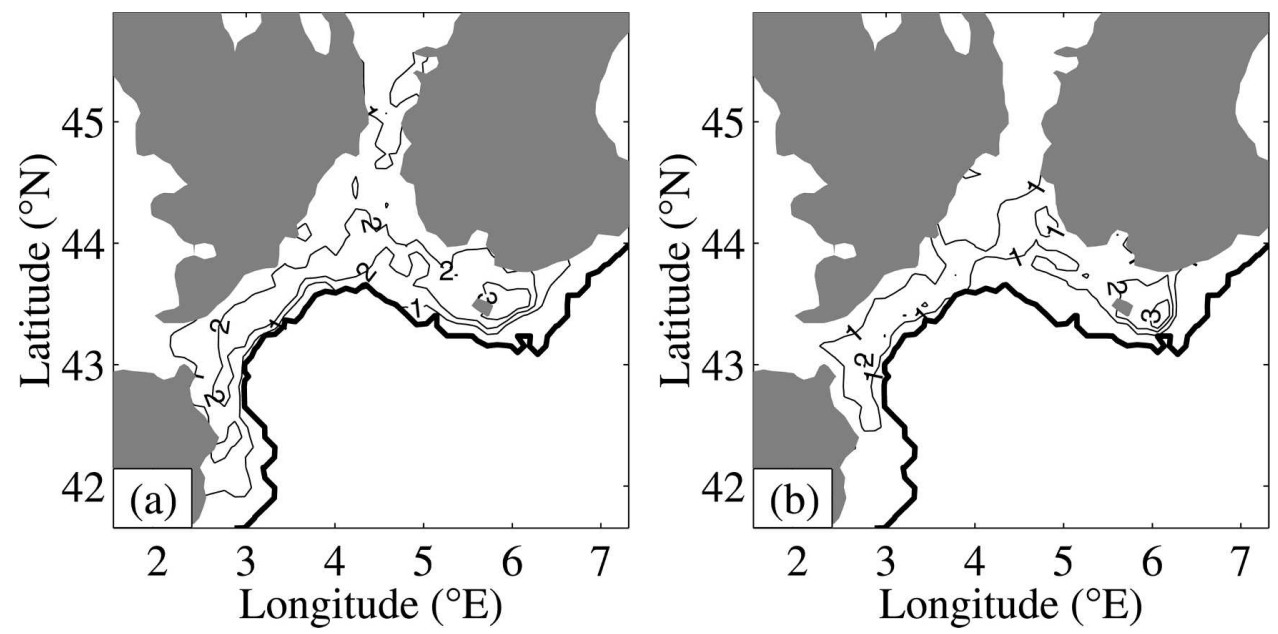

FIG. 12. Simulated 400 m AGL turbulent kinetic energy over the Rhône Valley delta at (a) 1100 and (b) 1700 UTC 22 Jun 2001 from model domain 1 . Contour interval is $1 \mathrm{~m}^{2} \mathrm{~s}^{-3}$ from 1 to $3 \mathrm{~m}^{2} \mathrm{~s}^{-3}$. 

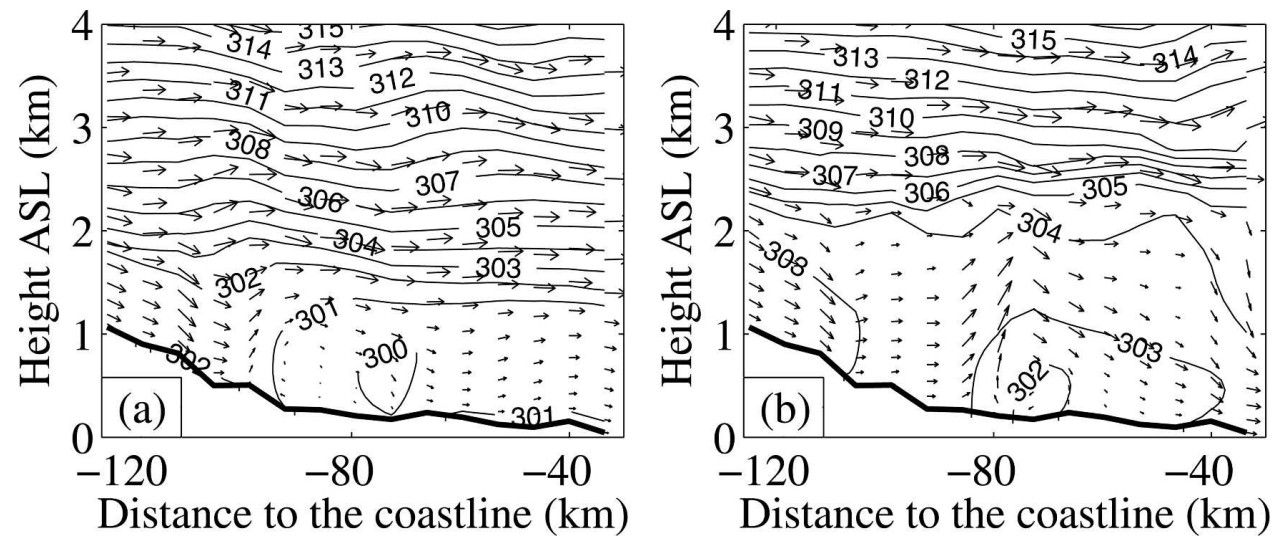

FIG. 13. Same as Fig. 10 but along section D2 transecting the northern Massif Central (see Fig. 9a) at (a) 1100 and (b) 1700 UTC 22 Jun 2001

to the reinforcement of the mistral flow, which in turn moves the sea-breeze front about $8 \mathrm{~km}$ offshore (Fig. 10d; Estoque 1962; Arritt 1993). Similarly to the situation at 1100 UTC, the largest TKE values are found at the sea-breeze front skirting slightly offshore along the coast (Fig. 12b). However, the background TKE value has decreased because of decreasing radiative heating.

Downstream of the northern slopes of the Massif Central, a persistent region of low wind speed is visible in Fig. 9 and corresponds to the wake trailing downstream of the Massif Central, which delimits the western boundary of the mistral as shown by Jiang et al. (2003) and Guénard et al. (2005b, hereafter GDC) (autumn cases) and Drobinski et al. (2005) (summer case). These studies show that this wake is caused by the occurrence of a hydraulic jump on the leeward side of the Massif Central. Figure 13 is similar to Fig. 10 at 1100 and 1700 UTC along section D2 transecting the northern part of the Massif Central and indicated in Fig. 9a. It shows evidence of the hydraulic jump occurrence associated with flow deceleration from 7 to $5 \mathrm{~m} \mathrm{~s}^{-1}$. At 1100 UTC, the wake has a large horizontal extension and is found offshore, at about $43.2^{\circ} \mathrm{N}$ and $4^{\circ} \mathrm{E}$ immediately to the north of the Tramontane flow, similar to the cases studied by Jiang et al. (2003), GDC, and Drobinski et al. (2005). Figure 12a confirms hydraulic jump occurrence since it shows that along the northern slopes of the Massif Central, large values of TKE corresponding to the hydraulic jump that contributes to the wake formation are found at the same location where the hydraulic jump is diagnosed by Drobinski et al. (2005) for the 28 June 2001 mistral case (i.e., along section $44.5^{\circ} \mathrm{N}, 3.8^{\circ} \mathrm{E}-45^{\circ} \mathrm{N}, 4.2^{\circ} \mathrm{E}$ ). At $1700 \mathrm{UTC}$, the horizontal extension of the wake has considerably decreased as also shown by much weaker TKE values (Fig. 12b). The wake is disrupted by the mistral flowing over the southwesterly part of the Massif Central (see Fig. 10d) and blowing closer to the western flank of the northern part of the Rhône Valley as shown in Fig. 9b. The mean sea level pressure field shows a surface low deepening at 1400 and 1700 UTC in the region of the wake that tends to suck in the mistral flowing along the eastern flank of the Rhône Valley.

\section{b. Eastern side of the Rhône Valley}

In the middle of the Rhône Valley, the delay of the sea-breeze onset over land is due to (i) the northerly mistral flow that maintains the sea-breeze front offshore (Arritt 1993) and (ii) the continental colder air advection by the mistral that partly compensates radiative heating. Figure 14 shows a vertical cross section of the along-section wind field $\left(v_{h}-w\right)$ and isentropes along the Rhône Valley at 1100 and 1700 UTC. At 1100 UTC, Figs. 3c, 3d, 9a, and 14a show that the mistral accelerates where the valley is the narrowest near Valence. The studies by Pettré (1982), Drobinski et al. (2005), and Corsmeier et al. (2005) have shown that conditions are often propitious to hydraulic jump occurrence downstream in the Rhône Valley. In the present case, despite upstream conditions favorable to hydraulic jump occurrence [the 1100 UTC radiosounding launched from Lyon and shown in Fig. 4 gives an upstream Froude number (ratio between the velocity of the fluid and the velocity of the gravity wave at the base of the inversion layer) of 0.28 , which is the minimum value favorable to hydraulic jump occurrence; see Pettré 1982], Fig. 14a does not show evidence of flow deceleration associated with PBL deepening which is the main feature of hydraulic jump occurrence. A reason why the flow does not transition to subcritical regime is that the wake trailing downstream of the Massif 

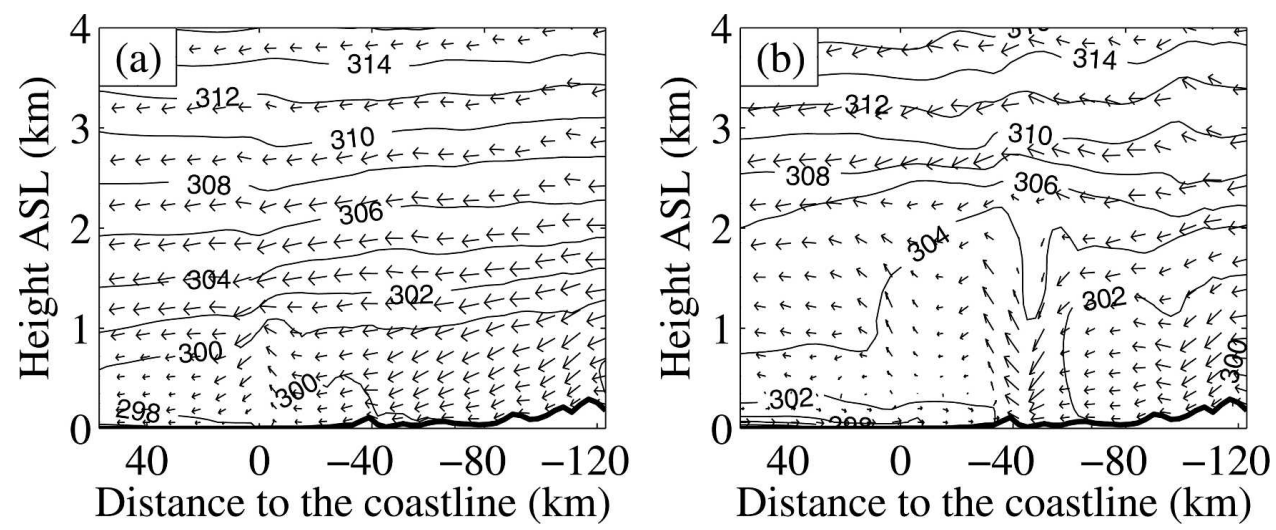

FIG. 14. Same as Fig. 10 but along the Rhône Valley at (a) 1100 and (b) 1700 UTC 22 Jun 2001.

Central acts as a virtual sidewall that channels the mistral flow, thus preventing flow deceleration (Fig. 9a). Indeed at 1100 UTC, Fig. 11b shows that, at the exact location of the Massif Central wake, the mean sea level pressure is constant and equal to $1012.6 \mathrm{hPa}$. East of the eastern wake boundary, the isobars show a continuously increasing along-wind pressure gradient in the direction of the southeast along the eastern flank of the Rhône Valley, evidencing the acceleration of the flow between the maximum constriction and the exit of the Rhône Valley. Figure 12a shows large TKE values in the middle and eastern side of the Rhône Valley due to shear production of TKE within the mistral flow (Caccia et al. 2004). On the contrary, at 1400 and 1700 UTC, Fig. 11d shows that convection contributes to decrease the mean sea level pressure in the middle of the Rhône Valley: the mean sea level pressure minimum is located at $43.8^{\circ} \mathrm{N}$ at $1400 \mathrm{UTC}(1011.7 \mathrm{hPa})$ and at about $44^{\circ} \mathrm{N}$ at $1700 \mathrm{UTC}(1011.1 \mathrm{hPa})$. This mean sea level pressure minimum contributes to sea-breeze inland penetration and strong frontogenesis as the sea breeze collides with the mistral. The stably stratified sea-breeze flow (Fig. $14 \mathrm{~b}$ ) is associated with absence of TKE production, and a distinct separation is visible between the sea breeze and the mistral, which is, on the contrary, associated with large TKE values (Fig. 12b). The adverse pressure gradient leads to boundary layer separation of the mistral, which is lifted up above the sea-breeze flow. From a hydraulic point of view, the presence of the seabreeze flow creates the downstream conditions favorable to hydraulic jump occurrence upstream of the seabreeze front at about $44^{\circ} \mathrm{N}$ since the air is nearly at rest at the sea-breeze front (Drobinski et al. 2001a). The strength of the mistral flow prevents the sea-breeze flow from penetrating very far inland: in the present case, the maximum inland penetration in the middle of the Rhône Valley is about $40 \mathrm{~km}$ at 1700 UTC and is to be compared to the $100-\mathrm{km}$ inland penetration on 25 June 2001 (when a weak northerly blows within the Rhône Valley) and to the $150-\mathrm{km}$ inland penetration on 26 June 2001 (in presence of a slight prevailing southerly flow) (Bastin et al. 2005b).

Farther to the east, near Marseille, the sea breeze penetrates late in the afternoon at about 1500 UTC. On 25 June 2001, the sea breeze starts blowing over Marseille at 0800 UTC, and on 26 June 2001 at 1000 UTC (on this day, the prevailing onshore flow tends to delay the land-sea temperature contrast by advecting cold marine air over land; Bastin et al. 2005b). Figure 3 shows that at 1700 UTC, the sea breeze penetrates on a $25-\mathrm{km}$ horizontal range. Figure 15 , which displays a vertical cross section of the along-section wind field $\left(v_{h}-\right.$ $w)$ and isentropes transecting the western Alps at 1700 UTC along line D3 (Fig. 9a), shows that the late and

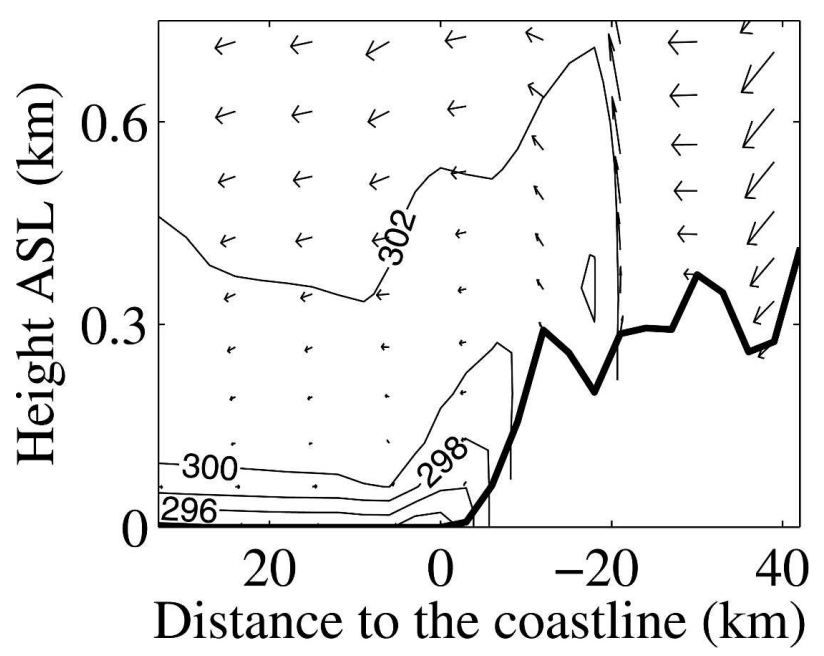

FIG. 15. Same as Fig. 10 but along section D3 transecting the western Alps over Marseille (see Fig. 9a) at 1700 UTC 22 Jun 2001. 

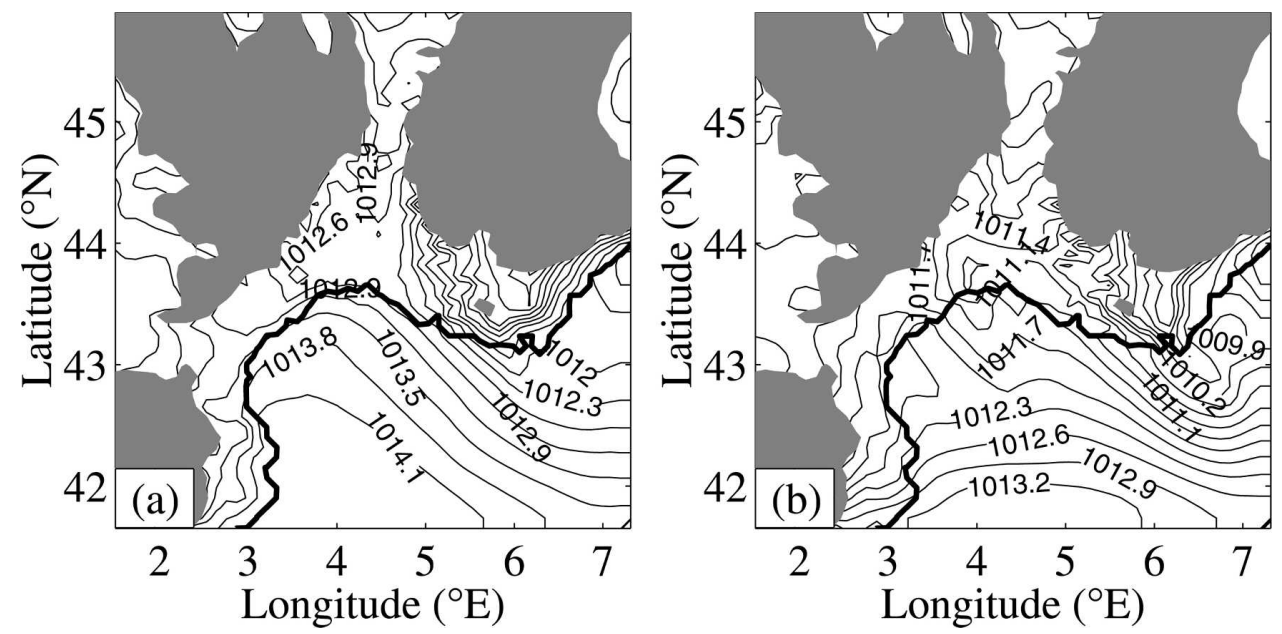

FIG. 16. Simulated mean sea level pressure (hPa) throughout the domain 1, on 22 Jun 2001 at (a) 1100 and (b) 1700 UTC 22 Jun 2001.

limited penetration range is caused (i) by the mistral, which is most intense in this area (see also Fig. 9b), and thus prevents sea-breeze penetration, and (ii) by the local topography that can reach several hundreds of meters around Marseille, which is another obstacle to sea-breeze penetration.

The sea-breeze flow also has an impact on the structure of the mistral flow along the eastern flank of the Rhône Valley. Indeed, the sea-breeze front acts as a barrier that redirects the mistral and enhances its cyclonic curvature as it exits the Rhône Valley. The mistral is thus confined between the sea-breeze front and the western Alps flank where it reaccelerates. Indeed, the along-wind mean sea level pressure gradient in the easternmost part of the domain shown in Fig. 11 is equal to $1.5 \times 10^{-2} \mathrm{hPa} \mathrm{km}^{-1}$ at $0900 \mathrm{UTC}, 2.25 \times 10^{-2} \mathrm{hPa} \mathrm{km}^{-1}$ at $1100 \mathrm{UTC}, 3.0 \times 10^{-2} \mathrm{hPa} \mathrm{km}^{-1}$ at $1400 \mathrm{UTC}$, and $3.75 \times 10^{-2} \mathrm{hPa} \mathrm{km}^{-1}$ at 1700 UTC. It demonstrates the effect of constriction by the sea breeze, which "squeezes" the mistral flow between the sea-breeze front and the eastern flank of the Rhône Valley. The wake trailing downstream the western Alps east of $6^{\circ} \mathrm{E}$ longitude with flow reversal (Fig. 9a) is due to flow separation caused by dissipation in an oblique hydraulic jump (or flank shock; Schär and Smith 1993). The oblique jump is easily discernable since at the location where it occurs, a maximum of turbulent kinetic energy is created (Fig. 12). However, despite the very persistent pattern of the TKE field in this area, Fig. 16, which displays the mean sea level pressure field of model domain 1 , shows that downstream flow separation the mean sea level pressure field evolves substantially between 1100 and 1700 UTC. At 1100 UTC, the downstream mean sea level pressure pattern is very similar to that of a pure mistral event such that of 28 June 2001 (Drobinski et al. 2005). At 1700 UTC, convection over land and the associated sea-breeze flow in the western Alps wake region (region of no TKE) contributes to distort the mean sea level pressure field. This "seabreeze air mass" forms a secondary pressure low visible at $43.3^{\circ} \mathrm{N}$ and $7^{\circ} \mathrm{E}$ in Fig. $16 \mathrm{~b}$, which creates a secondary cyclone that maintains the mistral away from the Alps flank. In the afternoon, the origin of flow separation thus differs from that discussed by Drobinski et al. (2005) for the 28 June 2001 mistral event. During the 28 June 2001 mistral event, the Alpine wake is caused by a combination of flow separation and hydraulic-jumpinduced dissipation of the flow descending the Alps slope from the north. In the present case, the Alpine wake is caused by oblique hydraulic-jump-induced flow separation reinforced by the presence of sea-breeze airmass downstream flow separation occurrence. In addition, the downslope wind blowing along the southern slope of the Alps does not experience any hydraulic jump: in fact, Fig. 17, which displays a vertical cross section of the along-section wind field $\left(v_{h}-w\right)$ and isentropes transecting the western Alps at 1100 and at 1700 UTC along section D4 (Fig. 9a), shows no evidence of hydraulic jump along the Alps slope and advocates for a disconnection between the low-level wake (below $1 \mathrm{~km} \mathrm{ASL}$ ) induced by flow separation and the descending air masses that flow over the recirculating flow. Compared to the 28 June 2001 mistral case at approximately the same time, the mistral sticks to the Alps sidewalls much longer on 22 June 2001. Two reasons can be invoked: (i) the mistral wind is much weaker; (ii) the upstream stagnation point is located more to the south than for the 28 June 2001 mistral 

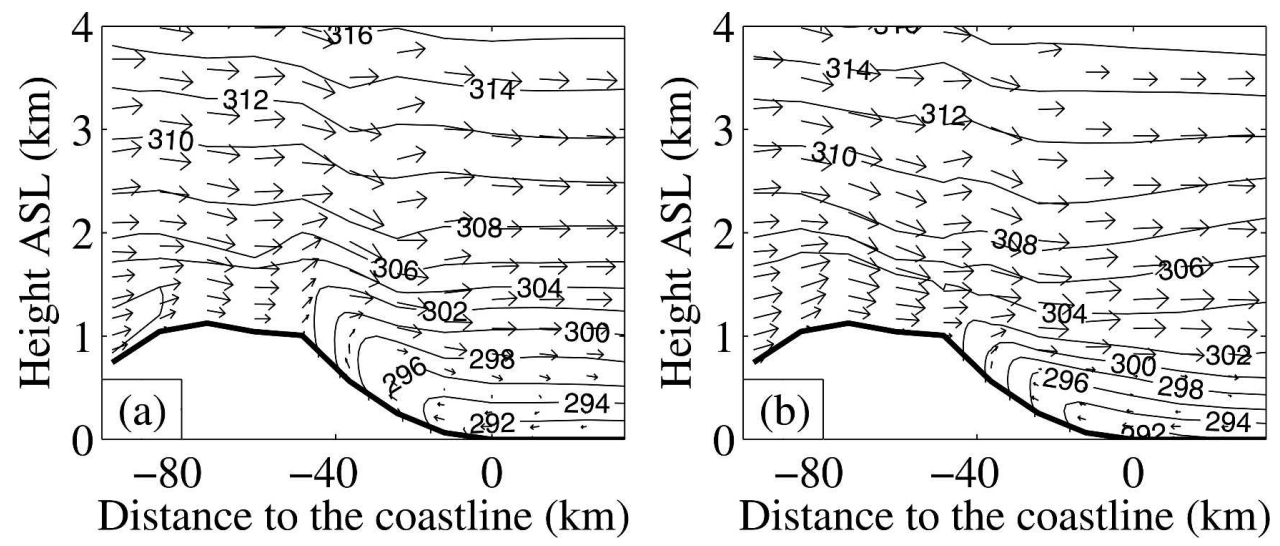

FIG. 17. Same as Fig. 10 along section D4 transecting the western Alps (see Fig. 9a) at (a) 1100 and (b) 1700 UTC 22 Jun 2001.

case, because of the northwest direction of the impinging flow.

\section{Summary}

This study has pointed out the complexity of the structure of the mistral and the sea breeze on 22 June 2001. Indeed, it is shown that on 22 June 2001, the sea breeze displays a large horizontal heterogeneity that is not present on pure sea-breeze events (Bastin et al. $2005 b$ ). The sea-breeze asymmetry between the western and eastern sides of the Rhône Valley and its unsteadiness are highly correlated with the different mechanisms that drive the mistral flow over these two regions. We find the following:

- West of the domain (downstream of the Massif Central), the sea breeze commences at about 1000 UTC. The sea-breeze onset is facilitated by the wake trailing downstream the massif due to dissipation in hydraulic jump occurring on the leeward slope of the Massif Central (corresponding to large mechanical production of turbulent kinetic energy). Later in the afternoon, the deepening of the leeward surface low due to radiative-heating-induced convection favors the intensification of the mistral that descends the Massif Central slope and stops the sea-breeze inland propagation. At $1700 \mathrm{UTC}$, the mistral pushes the sea-breeze front offshore, marking the cessation of the sea breeze in this area. Strong mixing evidenced by large turbulent kinetic energy value is found at the sea-breeze front.

- In the middle of the Rhône Valley, the mistral experiences acceleration at the maximum construction near Valence as generally seen in previous studies (Pettré 1982; Drobinski et al. 2005; Corsmeier et al.
2005). At 1100 UTC, the Massif Central wake acts as a virtual sidewall that forces the channeling of the mistral, which continuously accelerates along the Rhône Valley (the along-wind mean sea level pressure gradient increases in the direction of the south). At 1700 UTC, convection has contributed to form a pressure minimum in the middle of the Rhône Valley. This has two antagonist effects: (i) it promotes sea-breeze circulation due to cross-shoreline pressure gradient and (ii) contributes to intensify the mistral, which continues to accelerate south of the maximum constriction until it collides with the sea-breeze front over land about $40 \mathrm{~km}$ from the shore (i.e., about $44^{\circ} \mathrm{N}$ ) inducing a hydraulic-jump-like boundary layer separation. Because of the mistral blowing from the north and advecting a continental colder and dryer air mass (Bastin et al. 2005a), the sea breeze takes longer to penetrate inland and the inland propagation hardly reaches $40 \mathrm{~km}$ from the shore.

- East of the domain, the sea-breeze front acts as a barrier that reinforces and redirects the mistral flow, enhancing the cyclonic curvature of the mistral when it exits the Rhône Valley. The mistral is thus confined between the sea-breeze front and the western Alps flank, as revealed by the mean sea level pressure pattern. At about $6^{\circ} \mathrm{E}$ longitude, flow separation, associated with energy dissipation in an oblique jump, occurs inducing a wake associated with flow reversal similar to the 28 June 2001 mistral case (Drobinski et al. 2005), in good agreement with the prediction of Schär and Smith (1993) theory. The oblique jump is easily discernable since at the location where it occurs, a maximum of turbulent kinetic energy is created. Despite the very persistent structure of the oblique jump, sea-breeze flow development downstream of flow separation also contributes to 
TABLE 2. Sea-breeze main characteristics in the Marseille area in the sea-breeze-only situation (from Bastin et al. 2005b) and in the combined sea breeze and mistral situation.

\begin{tabular}{|c|c|c|}
\hline Feature & Sea breeze only & $\begin{array}{l}\text { Sea breeze } \\
\text { and mistral }\end{array}$ \\
\hline Sea-breeze onset & $\begin{array}{l}\text { Between } 0800 \text { and } \\
1000 \text { UTC }\end{array}$ & After 1500 UTC \\
\hline Sea-breeze depth & Up to $1500 \mathrm{~m}$ & $<1000 \mathrm{~m}$ \\
\hline Sea-breeze direction & Southwest & West \\
\hline Sea-breeze intensity & About $5 \mathrm{~m} \mathrm{~s}^{-1}$ & About $5 \mathrm{~m} \mathrm{~s}^{-1}$ \\
\hline Inland penetration & About $100 \mathrm{~km}$ & $<50 \mathrm{~km}$ \\
\hline
\end{tabular}

maintain the mistral away from the Alps flank in the afternoon. The air that flows over the western Alps from the north blows over the western Alps wake, which prevents mixing with the air coming from aloft.

Finally, the description of the flow blowing in the region of Marseille allows us to compare the sea-breeze main features studied by Bastin et al. (2005b) for situations of sea breeze only with those for the present situation of combined sea breeze and mistral. The summary of this comparison is reported in Table 2. It clearly shows that the cold and dry mistral flows blowing against the sea breeze (i) delays the sea-breeze onset at Marseille; (ii) limits the vertical and horizontal extents of the sea breeze; and (iii) redirects the sea breeze.

Such combined sea-breeze/mistral events generate the highest pollution levels nearby the emission sources, which are also the most densely inhabited area in southeastern France (Marseille has about one million inhabitants). The highly unsteady and inhomogeneous structure of the sea breeze at the Rhône Valley exit, as well as the small inland penetration (less than $40 \mathrm{~km}$ ) make difficult the accurate and reliable prediction of such events. Models with high-resolution mesh grid are obviously needed to address this issue.

Acknowledgments. This work was conducted at Service d'Aéronomie and Laboratoire de Météorologie Dynamique of the Institut Pierre Simon Laplace. The authors thank the two anonymous referees for their relevant comments, which helped to improve the manuscript significantly; R. Benamara and R. Vautard for fruitful discussion; M. C. Lanceau for help in collecting the referenced papers; and B. Cros and P. Durand for the coordination of the experiment. The flights of the DLR Falcon were funded partly by the Coordinated Access to Aircraft for Transnational Environmental Research (CAATER) program of the European Commission. We would also like to thank E. Nagel (DLR) for assistance in operation of the WIND system, the pilots of the DLR flight facility R. Welser and M. Hinterwaldner, the Falcon technician, and the great support of the CAATER facilator A. Giez (DLR). In the framework of the French programs PNCA and PRIMEQUAL-PREDIT, ESCOMPTE was performed thanks to funding from the Ministère de l'Écologie et du Développement Durable (MEDD), the Agence de l'Environnement et de la Maîtrise de l'Énergie (ADEME), the Institut National des Sciences de l'Univers (INSU), Météo-France, the Institut National de l'Environnement Industriel et des Risques (INERIS), the German funding agency (BMBF), the Institute for Meteorology and Climate Research (IMKKarlsruhe), the Joint Research Center (JRC-Ispra), the Swiss Federal Institute of Technology (EPFLLausanne), the Centre National d'Études Spatiales (CNES), Électricité de France (EDF), the air quality agencies Airmaraix and Airfobep, the cities of Marseilles and Aix-en-Provence, and the county council of the Bouches-du-Rhône. We particularly thank M. P. Lefebvre who played a crucial role in the delicate organization of the flights.

\section{REFERENCES}

Arritt, R. W., 1993: Effects of the large-scale flow on characteristics features of the sea breeze. J. Appl. Meteor., 32,116-125.

Bastin, S., and P. Drobinski, 2005a: Sea breeze induced mass transport over complex terrain in southeastern France: A case study. Quart. J. Roy. Meteor. Soc., in press.

_ and $\_$, 2005b: Temperature and wind velocity oscillations along a gentle slope during sea-breeze events. Bound.-Layer Meteor., 114, 573-594.

- C. Champollion, O. Bock, P. Drobinski, and F. Masson, 2005a: On the use of GPS tomography to investigate water vapor variability during a mistral/sea breeze event in southeastern France. Geophys. Res. Let., 32, L05808, doi:10.1029/ 2004 GL021907.

_ P. Drobinski, A. M. Dabas, P. Delville, O. Reitebuch, and C. Werner, 2005b: Impact of the Rhône and Durance Valleys on sea-breeze circulation in the Marseille area. Atmos. Res., 74, 303-328.

Bechtold, P., E. Bazile, F. Guichard, P. Mascart, and E. Richard, 2001: A mass flux convection scheme for regional and global models. Quart. J. Roy. Meteor. Soc., 127, 869-886.

Bougeault, P., and P. Lacarrère, 1989: Parameterization of orography-induced turbulence in a meso-beta scale model. Mon. Wea. Rev., 117, 1872-1890.

Caccia, J.-L., V. Guénard, B. Bénech, B. Campistron, and P. Drobinski, 2004: Vertical velocity and turbulence aspects during mistral events as observed by UHF wind profilers. Ann. Geophys., 22, 3927-3936.

Caya, D., and I. Zawadzki, 1992: VAD analysis of nonlinear wind fields. J. Atmos. Oceanic Technol., 9, 575-587.

Corsmeier, U., R. Behrendt, P. Drobinski, and C. Kottmeier, 2005: The mistral and its effect on air pollution transport and vertical mixing. Atmos. Res., 74, 275-302.

Cros, B., and Coauthors, 2004: The ESCOMPTE program. An overview. Atmos. Res., 69, 241-279. 
Delbarre, S., and Coauthors, 2005: Ground-based remote sensing observation of the complex behaviour of the Marseille boundary layer during ESCOMPTE. Atmos. Res., 74, 403433.

Drobinski, P., J. Dusek, and C. Flamant, 2001a: Diagnostics of hydraulic jump and gap flow in stratified flows over topography. Bound.-Layer Meteor., 98, 475-495.

, C. Flamant, J. Dusek, P. H. Flamant, and J. Pelon, 2001b: Observational evidence and modeling of an internal hydraulic jump at the atmospheric boundary-layer top during a Tramontane event. Bound.-Layer Meteor., 98, 497-515.

—, C. Haeberli, E. Richard, M. Lothon, A. M. Dabas, P. H. Flamant, M. Furger, and R. Steinacker, 2003: Scale interaction processes during the MAP IOP 12 south foehn event in the Rhine Valley. Quart. J. Roy. Meteor. Soc., 129, 729-753.

—, and Coauthors, 2005: Summer mistral at the exit of the Rhône Valley. Quart. J. Roy. Meteor. Soc., 131, 353-375.

Estoque, M. A., 1962: The sea breeze as a function of the prevailing synoptic situation. J. Atmos. Sci., 19, 244-250.

Georgelin, M., and E. Richard, 1996: Numerical simulation of flow diversion around the Pyrenées: A Tramontana case study. Mon. Wea. Rev., 124, 687-700.

Guénard, V., P. Drobinski, J.-L. Caccia, B. Campistron, and B. Bénech, 2005a: An observational study of the mesoscale mistral dynamics. Bound.-Layer Meteor., 115, 263-288.

,,--- G. Tedeschi, and P. Currier, 2005b: Dynamics of the MAP IOP-15 severe mistral event: Observations and high-resolution numerical simulations. Quart. J. Roy. Meteor. Soc., in press.

Jansá, A., 1987: Distribution of the mistral: A satellite observation. Meteor. Atmos. Phys., 36, 201-214.

Jiang, Q., R. B. Smith, and J. D. Doyle, 2003: The nature of the mistral: Observations and modeling of two MAP events. Quart. J. Roy. Meteor. Soc., 129, 857-876.

Lafore, J. P., and Coauthors, 1998: The Meso-Nh atmospheric simulation system. Part I: Adiabatic formulation and control simulation. Ann. Geophys., 16, 90-109.

Lemonsu, A., S. Bastin, V. Masson, and P. Drobinski, 2005: Vertical structure of the urban boundary layer over Marseille under sea breeze condition. Bound.-Layer Meteor., in press.

Menut, L., I. Coll, and S. Cautenet, 2005: Impact of meteorological data resolution on the forecasted ozone concentrations during ESCOMPTE IOP2a and IOP2b. Atmos. Res., 74, 139159.

Morcrette, J.-J., 1991: Radiation and cloud radiative properties in the European Centre for Medium Range weather forecasts forecasting system. J. Geophys. Res., 96, 9121-9132.

Noilhan, J., and S. Planton, 1989: A simple parameterization of land surface processes for meteorological models. Mon. Wea. Rev., 117, 536-549.

Pettré, P., 1982: On the problem of violent valley wind. J. Atmos. Sci., 39, 542-554.

Puygrenier, V., F. Lohou, B. Campistron, F. Saïd, G. Pigeon, B. Bénech, and D. Serca, 2005: Investigation on the fine structure of sea-breeze during ESCOMPTE experiment. Atmos. Res., 74, 329-353.

Reitebuch, O., C. Werner, I. Leike, P. Delville, P. H. Flamant, A. Cress, and D. Engelbart, 2001: Experimental validation of wind profiling performed by the airborne $10-\mu \mathrm{m}$ heterodyne Doppler lidar WIND. J. Atmos. Oceanic Technol., 18, 13311344.

, H. Volkert, C. Werner, A. M. Dabas, P. Delville, P. Drobinski, P. H. Flamant, and E. Richard, 2003: Determination of airflow across the Alpine Ridge by a combination of Doppler lidar, routine radiosounding and numerical simulation. Quart. J. Roy. Meteor. Soc., 129, 715-727.

Schär, C., and R. B. Smith, 1993: Shallow-water flow past isolated topography. Part I: Vorticity production and wake formation. J. Atmos. Sci., 50, 1373-1400.

Werner, C., and Coauthors, 2001: Wind infrared Doppler lidar instrument. Opt. Eng., 40, 115-125. 